\title{
The tropical forest and fire emissions experiment: laboratory fire measurements and synthesis of campaign data
}

\author{
R. J. Yokelson ${ }^{1}$, T. J. Christian ${ }^{1}$, T. G. Karl ${ }^{2}$, and A. Guenther ${ }^{2}$ \\ ${ }^{1}$ University of Montana, Department of Chemistry, Missoula, MT, USA \\ ${ }^{2}$ National Center for Atmospheric Research, Boulder, CO, USA \\ Received: 3 January 2008 - Published in Atmos. Chem. Phys. Discuss.: 3 March 2008 \\ Revised: 30 May 2008 - Accepted: 4 June 2008 - Published: 4 July 2008
}

\begin{abstract}
As part of the Tropical Forest and Fire Emissions Experiment (TROFFEE), tropical forest fuels were burned in a large, biomass-fire simulation facility and the smoke was characterized with open-path Fourier transform infrared spectroscopy (FTIR), proton-transfer reaction mass spectrometry (PTR-MS), gas chromatography (GC), GC/PTRMS, and filter sampling of the particles. In most cases, about one-third of the fuel chlorine ended up in the particles and about one-half remained in the ash. About 50\% of the mass of non-methane organic compounds (NMOC) emitted by these fires could be identified with the available instrumentation. The lab fire emission factors (EF, g compound emitted per kg dry fuel burned) were coupled with EF obtained during the TROFFEE airborne and ground-based field campaigns. This revealed several types of EF dependence on parameters such as the ratio of flaming to smoldering combustion and fuel characteristics. The synthesis of data from the different TROFFEE platforms was also used to derive $\mathrm{EF}$ for all the measured species for both primary deforestation fires and pasture maintenance fires - the two main types of biomass burning in the Amazon. Many of the $\mathrm{EF}$ are larger than those in widely-used earlier work. This is mostly due to the inclusion of newly-available, large $\mathrm{EF}$ for the initially-unlofted smoldering emissions from residual logs in pastures and the assumption that these emissions make a significant contribution $(\sim 40 \%)$ to the total emissions from pasture fires. The TROFFEE EF for particles with aerodynamic diameter $<2.5$ microns $\left(\mathrm{EFPM}_{2.5}\right)$ is $14.8 \mathrm{~g} / \mathrm{kg}$ for primary deforestation fires and $18.7 \mathrm{~g} / \mathrm{kg}$ for pasture maintenance fires. These $\mathrm{EFPM}_{2.5}$ are significantly larger than a previous recommendation $(9.1 \mathrm{~g} / \mathrm{kg})$ and lead to an estimated pyrogenic primary $\mathrm{PM}_{2.5}$ source for the Amazon that is $84 \%$ larger. New regional budgets for biogenic and pyrogenic
\end{abstract}

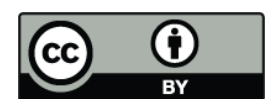

Correspondence to: R. J. Yokelson (bob.yokelson@umontana.edu) emissions were roughly estimated. Coupled with an estimate of secondary aerosol formation in the Amazon and source apportionment studies, the regional budgets suggest that $\sim 5 \%$ of the total mass of the regionally generated NMOC end up as secondary organic aerosol within the Amazonian boundary layer within 1-3 days. New global budgets confirm that biogenic emissions and biomass burning are the two largest global sources of NMOC with an estimated production of approximately $1000(770-1400)$ and $500(250-630) \mathrm{Tg} / \mathrm{yr}$, respectively. It follows that plants and fires may also be the two main global sources of secondary organic aerosol. A limited set of emission ratios (ER) is given for sugar cane burning, which may help estimate the air quality impacts of burning this major crop, which is often grown in densely populated areas.

\section{Introduction}

Biomass burning and biogenic emissions are the two largest sources of volatile organic compounds (VOC) and fine particulate carbon in the global troposphere. Tropical forests produce about one-third of the global biogenic emissions and tropical deforestation fires account for $>15 \%$ of the global biomass burning (Andreae and Merlet, 2001; Kreidenweis et al., 1999; Guenther et al., 2006). Numerous studies have measured the emissions from forest vegetation and deforestation fires in the tropics including e.g.: Rasmussen and Khalil (1988), Crutzen et al. (1985), and Ferek et al. (1998). The Tropical Forest and Fire Emissions Experiment (TROFFEE) used new instrumentation to quantify the emissions from tropical deforestation fires and tropical vegetation in laboratory experiments (October 2003) and airborne and ground based field campaigns during the 2004 Amazonian dry season (see Yokelson et al., 2007a, for an overview). Four previously published TROFFEE papers focused on:

Published by Copernicus Publications on behalf of the European Geosciences Union. 
Table 1. Tropical and temperate fuels.

\begin{tabular}{|c|c|c|c|c|c|c|c|c|c|}
\hline Type & $\mathrm{ID}^{\mathrm{a}}$ & Fuel Name ${ }^{b}$ & Common Name/Description & $\% \mathrm{C}$ & $\% \mathrm{H}$ & $\% \mathrm{~N}$ & $\begin{array}{l}\% \text { Ash } \\
\text { (in analyzer) }\end{array}$ & $\begin{array}{l}\text { Ash-free } \\
\text { Carbon }^{c}\end{array}$ & $\% \mathrm{FM}^{\mathrm{d}}$ \\
\hline \multirow[t]{14}{*}{ Tropical } & $\mathrm{Ar}$ & Artocarpus altilus & Breadfruit (widespread) & 43.3 & 5.65 & 2.96 & 12.2 & 0.49 & 9.42 \\
\hline & $\mathrm{Ca}$ & Calliandra haematocephala & Powderpuff (Brazil native) & 47.4 & 5.58 & 2.09 & 4.80 & 0.50 & 7.36 \\
\hline & $\mathrm{Cc}$ & Theobroma cacao & Chocolate tree (widespread) & 47.2 & 5.67 & 0.87 & 4.30 & 0.49 & 6.03 \\
\hline & $\mathrm{Db}$ & $\operatorname{Dambo}^{\mathrm{e}}$ & African savanna grass & 46.3 & 5.90 & 0.23 & 3.35 & 0.48 & 7.33 \\
\hline & Ds & Davidson pruriens (2) & Davidson's plum (Australia native) & 49.9 & 5.93 & 1.66 & 5.80 & 0.53 & 6.37 \\
\hline & $\mathrm{Eu}$ & Eucalyptus sp. (2) & & 47.8 & 5.73 & 1.17 & 6.20 & 0.51 & 6.79 \\
\hline & Fi1 & Ficus sp. ${ }^{\mathrm{f}}$ & Fig (widespread) & 49.2 & 6.21 & 2.39 & 6.70 & 0.53 & 7.95 \\
\hline & Fi2 & Ficus sp. ${ }^{\mathrm{f}}$ & Fig (widespread) & 48.9 & 6.26 & 1.24 & 7.00 & 0.53 & 27.30 \\
\hline & $\mathrm{Ma}$ & Mangifera & Mango & 48.2 & 5.88 & 1.94 & 6.60 & 0.52 & 13.30 \\
\hline & $\mathrm{Ne}$ & Neraudia sp. & Nettle family (Hawaii native) & 36.5 & 4.28 & 2.20 & 24.1 & 0.48 & 14.44 \\
\hline & Ps & Psidium cattleianum & Strawberry guava (South America native) & 47.7 & 4.87 & 1.17 & 8.30 & 0.52 & 10.81 \\
\hline & $\mathrm{Sc}$ & Saccharum & Sugar Cane (widespread) & 48.8 & 6.20 & 1.57 & 5.50 & 0.52 & 8.58 \\
\hline & $\mathrm{Tc}$ & Tropical composite & $\begin{array}{l}\text { Roughly equal amounts of: } \\
\text { Cecropia sp. - Trumpet tree (widespread); } \\
\text { Sparmannia } \text { sp. - African linden (South Africa); } \\
\text { Munroidendron racemosum - monotypic (Hawaii); } \\
\text { Erythrina humeana - coral tree (widespread) }\end{array}$ & 47.3 & 5.91 & 2.83 & 4.30 & 0.49 & 8.59 \\
\hline & $\mathrm{Te}$ & Terminalia catappa & Tropical almond (widespread) & 43.6 & 5.04 & 1.40 & 9.60 & 0.48 & 5.20 \\
\hline \multirow[t]{2}{*}{ Temperate } & $\mathrm{Pp}$ & Excelsior/Ponderosa pine (7) & $\begin{array}{l}\text { Freshly cut green tree branches with dry } \\
\text { shredded aspen (excelsior) as starter fuel }\end{array}$ & 50.8 & 6.53 & 1.34 & 2.90 & 0.52 & $123.4^{\mathrm{g}}$ \\
\hline & $\begin{array}{l}\text { Sf } \\
\text { Sp }\end{array}$ & $\begin{array}{l}\text { Excelsior/Subalpine fir } \\
\text { Excelsior/Blue spruce (2) }\end{array}$ & & \multicolumn{6}{|c|}{ Use ponderosa pine $(\mathrm{Pp})$ values } \\
\hline
\end{tabular}

a Two-letter abbreviation for reference only within this study.

$\mathrm{b}$ Numbers in parentheses denote multiple fires from same fuel.

c Ash-free carbon $=\% \mathrm{C} /(100-\% \mathrm{Ash}(\mathrm{CHN}$ analyzer $))$.

${ }^{\mathrm{d}}$ Fuel moisture $($ dry weight $\%)=100 \times(($ wet - dry $) /$ dry $)$ e Data taken from Christian et al. (2003).

f Two separate ficus species.

g $\mathrm{C}: \mathrm{H}: \mathrm{N}$ and FM data based on one Ponderosa pine fire.
1. a detailed campaign overview and the airborne measurements of the emissions from fires (Yokelson et al., 2007a),

2. ground-based measurements of the emissions from smoldering logs (Christian et al., 2007),

3. airborne and ground-based measurements of biogenic emissions (Karl et al., 2007a), and

4. intercomparison of the instrumentation used in both the lab and field (Karl et al., 2007b).

This paper completes the series by presenting the lab-fire emission factors and demonstrating how the different elements of the TROFFEE campaign can be synthesized to improve our understanding of the tropical troposphere.

Field measurements can probe the actual fires that are of global significance and they have obvious priority in developing recommended emission factors, but measurements of lab fires can also be useful. The TROFFEE lab experiment was conducted for a number of reasons - both general and specific. In general, it is often possible to quantify more species from lab fires because smoke concentrations tend to be higher and it is easier to deploy more extensive instrumentation. Also, in the lab, one can capture and probe all the smoke from a whole fire, while the vast majority of the smoke from field fires must go unsampled. In the field, the possibility exists for over estimating the relative importance of strongly lofted flaming emissions from airborne platforms; or under estimating their importance from ground based platforms. Measuring the elemental composition of the fuel that actually burned is easier for laboratory fires, which then facilitates mass-balance studies that account for the fate of various elements in the fuel. A very serious disadvantage of laboratory fire simulations is the possibility that the lab fire emissions are different from fire emissions produced in the field. This is especially critical for tropical forest fuels as it is impractical to burn a diverse suite of large diameter tropical logs in the lab.

Reasons for carrying out our laboratory component that were specific to TROFFEE included:

1. Determine the proton-transfer reaction mass spectrometry (PTR-MS) sampling protocol for the field campaign (by identifying the significant mass/charge $(\mathrm{m} / \mathrm{z})$ ratios observed by PTR-MS in smoke).

2. Employ techniques in addition to those used in the field including: particle collection on filters, ash analyses, open-path Fourier transform infrared spectroscopy (FTIR), and gas chromatography coupled to PTR-MS (GC/PTR-MS).

3. Intercompare PTR-MS with open-path FTIR and GC/PTR-MS. The intercomparison showed good agreement in most cases, but also revealed important biomass 
burning emissions that are difficult to measure by FTIR (due to interference by water lines) or PTR-MS (due to low proton affinity or sampling losses).

4. Use GC/PTR-MS and FTIR to measure the fractional contribution for fire-emitted species that appear at the same $\mathrm{m} / \mathrm{z}$ in the PTR-MS (Karl et al., 2007b).

5. Measure the emissions from burning sugar cane, which are important, but were not accessible in our field study.

The laboratory experiment involved measuring the emissions from 32 fires that burned tropical forest fuels and a few other fuels (e.g. sugar cane, pine needles, and savanna grass). In this paper we present and discuss:

1. a partial accounting of the fate of the nitrogen, chlorine, and potassium in the biomass fuel in our lab fires,

2. a synthesis of the lab, ground, and airborne EF to derive recommended $\mathrm{EF}$ for primary tropical deforestation fires and tropical pasture maintenance fires,

3. new estimates of the biogenic and fire emissions of NMOC at the Amazon-basin and global scale with comments on the significance of the new information, and

4. emission ratios and emission factors for sugar cane fires.

\section{Experimental}

\subsection{Combustion facility}

The combustion facility at the Fire Sciences Laboratory measures $12.5 \mathrm{~m} \times 12.5 \mathrm{~m} \times 22 \mathrm{~m}$ high. A $1.6 \mathrm{~m}$ diameter exhaust stack with a $3.6 \mathrm{~m}$ inverted funnel opening extends from $\sim 2 \mathrm{~m}$ above the floor up through the ceiling. The room is continuously pressurized with outside air that has been conditioned for temperature and humidity, and is then vented through the stack, completely entraining the emissions from fires burning beneath the funnel. The fires were burned on a continuously weighed fuel bed. A sampling platform surrounds the stack at $17 \mathrm{~m}$ elevation where all the temperature, pressure, trace gas, and particle measurement equipment for this experiment was deployed except background $\mathrm{CO}_{2}$ (LICOR 6262). The emissions are well mixed in the stack at the height of the sampling platform. Additional details can be found in Christian et al. (2004).

\subsection{Fuel types and characterization}

Table 1 presents a list of fuel types, with genus and species where applicable, as well as a two-letter abbreviation for each fuel type (for reference purposes within this study). The list includes 16 tropical species provided by the University of Colorado, one dambo grass species obtained for previous laboratory experiments with savanna fuels (Christian et al., 2003) and three local, temperate forest tree species used primarily in the intercomparison portion of this work (Karl et al., 2007b). The plant material was limited to leaves, twigs, and branches of less than $\sim 30 \mathrm{~mm}$ diameter. This was intended to represent the small diameter fuels of typical, global deforestation fires; but does not include the large diameter logs, which contributed to the emissions measured in the field campaign. Table 1 also shows the dry weight percentage of carbon, hydrogen, and nitrogen in the bulk plant tissue; the percent ash residual in the CHN analyzer; the percentage of carbon in the organic (burnable) plant material (ash-free \%C); and the fuel moisture at the time of the fire $(100 \times($ wet-dry $) /$ dry $))$. We determined the production of ash and partially burned fuel for each fire by manually weighing these residuals. We determined the fuel moisture content by measuring the mass loss from pre-fire sub-samples after drying them overnight at $90^{\circ} \mathrm{C}$.

The results of additional elemental analysis by an independent laboratory (Columbia Analytical Services, Inc.) are given in Table 2. Chlorine and sulfur were determined via Parr bomb combustion and ion chromatography of the leachate for both the plant tissue and the ash from the fires. Plant tissue potassium was determined via acid digestion and ICP-OES (Inductively Coupled Plasma - Optical Emission Spectroscopy).

\subsection{Open-path FTIR}

The open path Fourier transform infrared spectrometer (OPFTIR) was positioned on the sampling platform so that the open white cell spanned the stack directly in the rising emissions stream for continuous ( $0.83 \mathrm{~s}$ resolution) scanning. The OP-FTIR system (Yokelson et al., 1997) includes a MIDAC model 2500 spectrometer; an open path White cell with $1.6 \mathrm{~m}$ base path, and an MCT (mercury-cadmium-telluride), $\mathrm{LN}_{2}$ cooled detector. The path length was set to $57.7 \mathrm{~m}$ and the spectral resolution was $0.5 \mathrm{~cm}^{-1}$. Before each fire, we scanned for 2-3 min to obtain a background spectrum, and then made absorbance spectra at $0.83 \mathrm{~s}$ resolution using this background spectrum. We then averaged every $\sim 10 \mathrm{ab}-$ sorbance spectra under conditions of slowly changing temperature and emissions to increase the signal to noise ratio.

We used classical least squares spectral analysis (Griffith, 1996; Yokelson and Bertschi, 2002) to retrieve excess mixing ratios for water $\left(\mathrm{H}_{2} \mathrm{O}\right)$, methane $\left(\mathrm{CH}_{4}\right)$, methanol $\left(\mathrm{CH}_{3} \mathrm{OH}\right)$, ethylene $\left(\mathrm{C}_{2} \mathrm{H}_{4}\right)$, phenol $\left(\mathrm{C}_{6} \mathrm{H}_{5} \mathrm{OH}\right)$, acetone $\left(\mathrm{CH}_{3} \mathrm{C}(\mathrm{O}) \mathrm{CH}_{3}\right)$, isoprene $\left(\mathrm{C}_{5} \mathrm{H}_{8}\right)$, hydrogen cyanide $(\mathrm{HCN})$, furan $\left(\mathrm{C}_{4} \mathrm{H}_{4} \mathrm{O}\right)$, nitric oxide $(\mathrm{NO})$, nitrogen dioxide $\left(\mathrm{NO}_{2}\right)$, and formaldehyde ( $\mathrm{HCHO})$. We used spectral subtraction (Yokelson et al., 1997) to retrieve excess mixing ratios for water $\left(\mathrm{H}_{2} \mathrm{O}\right)$, ammonia $\left(\mathrm{NH}_{3}\right)$, formic acid $(\mathrm{HCOOH})$, acetic acid $\left(\mathrm{CH}_{3} \mathrm{COOH}\right)$, glycolaldehyde $\left(\mathrm{CH}_{2}(\mathrm{OH}) \mathrm{CHO}\right)$, acetylene $\left(\mathrm{C}_{2} \mathrm{H}_{2}\right)$, and propylene $\left(\mathrm{C}_{3} \mathrm{H}_{6}\right)$. While $\mathrm{CO}_{2}$ and $\mathrm{CO}$ are accurately measured by OP-FTIR (Goode et al., 1999), due to the large volume of data, we opted to use the 
Table 2. Elemental analysis of plant tissue and emission factors (EF) for chlorine in ash and $\mathrm{PM}_{2.5}{ }^{\mathrm{a}}$.

\begin{tabular}{lcccccccc}
\hline \multirow{2}{*}{ ID } & \multicolumn{3}{c}{ Plant tissue } & Ash & \multicolumn{3}{c}{$\mathrm{PM}_{2.5}$} & \\
& $\mathrm{Cl}$ & $\mathrm{S}$ & $\mathrm{K}$ & $\mathrm{Cl}$ & $\mathrm{Cl}$ & $\mathrm{K}$ & $\mathrm{S}$ & Total \\
\hline $\mathrm{Ar}$ & 6.92 & 1.86 & 22.2 & 5.12 & 0.91 & 0.78 & 0.06 & 16.1 \\
$\mathrm{Ca}$ & 1.09 & 1.50 & 6.15 & 0.45 & 0.22 & 0.30 & 0.03 & 7.50 \\
$\mathrm{Cc}$ & 0.44 & 1.93 & 19.0 & 0.26 & 0.19 & 0.32 & 0.04 & 2.22 \\
$\mathrm{Db}^{\mathrm{b}}$ & 0.25 & - & - & 0.02 & 0.01 & 0.03 & 0.01 & 11.4 \\
$\mathrm{Ds}$ & 1.69 & 2.36 & 18.4 & 1.01 & 0.46 & 0.61 & 0.05 & 7.34 \\
$\mathrm{Eu}$ & 2.25 & 1.00 & 13.3 & 1.61 & 0.75 & 0.90 & 0.03 & 9.87 \\
$\mathrm{Fi} 1$ & 0.06 & 2.28 & 17.3 & & 0.07 & 0.43 & 0.09 & 10.4 \\
$\mathrm{Fi} 2$ & 0.23 & 1.16 & 13.4 & .13 & 0.12 & 0.57 & 0.06 & 16.3 \\
$\mathrm{Ma}$ & 1.00 & 1.57 & 8.48 & 0.37 & 0.47 & 0.64 & 0.04 & 5.81 \\
$\mathrm{Ne}$ & 1.14 & 14.5 & 8.64 & & - & - & - & - \\
$\mathrm{Ps}$ & 3.08 & 1.06 & 23.3 & & - & - & - & - \\
$\mathrm{Sc}$ & 2.03 & 1.77 & 12.4 & 0.55 & 0.87 & 1.38 & 0.12 & 2.17 \\
$\mathrm{Tc}$ & 8.69 & 2.15 & 25.8 & 4.31 & 0.80 & 0.92 & 0.05 & 13.5 \\
$\mathrm{Te}$ & 11.6 & 1.26 & 9.10 & 5.11 & 1.62 & 0.60 & 0.04 & 16.6 \\
$\mathrm{Pp}$ & 0.119 & 1.19 & 7.26 & - & - & - & - & - \\
$\mathrm{Sf}$ & $\mathrm{use}$ & $\mathrm{Pp}$ values & & - & - & - & - & - \\
$\mathrm{Sp}$ & & & & - & - & - & - & - \\
\hline
\end{tabular}

${ }^{a}$ Units: plant tissue, ash, and $\mathrm{PM}_{2.5} \mathrm{~g} / \mathrm{kg}$ dry fuel.

b Dambo CHN and Cl data from (Christian et al., 2003).

c Average of two fires from same species.

convenient, synchronized data for these molecules from the real-time instruments (Sect. 2.5). The molecules discussed above account for all the significant features observed from $600-3400 \mathrm{~cm}^{-1}$ in all the IR spectra. The detection limit for most gases was $10-50 \mathrm{ppb}$ at the most common time resolution used $(\sim 8 \mathrm{~s})$. The typical uncertainty in an FTIR mixing ratio is $\pm 5 \%(1 \sigma)$ due to calibration or the detection limit $(2 \sigma)$, whichever is greater.

\subsection{PTR-MS}

Background information on PTR-MS has been given in detail by Lindinger et al. (1998). The PTR-MS setup used here is described in more detail by Karl et al. (2007b). Briefly, $\mathrm{H}_{3} \mathrm{O}^{+}$is used to ionize volatile organic compounds (VOC) whose proton affinity is greater than that of water. In this study the mass analyzer of the PTR-MS was a conventional quadrupole mass filter (QMG 422, Balzers, Lichtenstein) with a mass range up to $\sim 500 \mathrm{amu}$ (atomic mass units). Because ion transmission of the quadrupole decreases as mass increases, scans were conducted only up to $205 \mathrm{amu}$. More details on instrument performance and calibration procedures can be found in Karl et al. (2007b).

In order to enhance the specificity of the VOC partitioning observed by the PTR-MS, we also used a gas chromatograph in line before the PTR-MS (GC/PTR-MS). If more than one compound was observed at a single $\mathrm{m} / \mathrm{z}$, the peaks were identified based on a combination of GC retention times and PTR-MS VOC fragmentation data. Sample air for this technique was taken either directly from the stack or from stainless steel canisters collected during a fire and analyzed immediately afterward. The sample was trapped on Tenax for $10 \mathrm{~min}$ at $-10^{\circ} \mathrm{C}$, then desorbed by heating to $200^{\circ} \mathrm{C}$ onto a $50 \mathrm{~m}$ HP-624 column (Shimadzu GC instrument), and analyzed using the PTR-MS instrument as the detector (Greenberg, 1994). Retention times were obtained individually by injecting pure standards. The contribution of various compounds to specific $\mathrm{m} / \mathrm{z}$ channels is treated in more detail by Karl et al. (2007b).

In these experiments the PTR-MS frequently scanned all $\mathrm{m} / \mathrm{z}$ up to 205 . The individual species that could be quantified typically accounted for $\sim 72 \%$ of the total ion signal up to $205 \mathrm{~m} / \mathrm{z}$ that was observed by this instrument. Thus about $70 \%$ of the NMOC that were emitted by these fires and detected by the PTR-MS have been individually quantified (on a molar basis). This is an important consideration in photochemical modeling of smoke chemistry as shown by Trentmann et al. (2005) who successfully modeled the $\mathrm{O}_{3}$ formation observed in a smoke plume after the measured initial NMOC were increased by $30 \%$ as a proxy for the unmeasured NMOC. In addition, most of the unidentified species occur at heavier masses, which are also transmitted less efficiently through the PTR-MS quadrupole. Therefore, on a mass basis, only about $50 \%$ of the NMOC emitted by these fires were individually quantified. This is important in estimating local-global pyrogenic budgets (e.g. Sect. 3.3).

\subsection{Particle, $\mathrm{CO}_{2}$ and $\mathrm{CO}$ measurements}

Stack air was drawn at $30 \mathrm{~L} \mathrm{~min}^{-1}$ through dielectric tubing and a cyclone that passed only particles with an aerodynamic diameter less than $2.5 \mu \mathrm{m}$ (PM2.5) onto Teflon filters. The filters were analyzed gravimetrically by the US Forest Service (Trent et al., 2000) and then by X-Ray Fluorescence (XRF) at an independent laboratory for chlorine, potassium, and sulfur. The same sample flow was used for continuous, in-stack $\mathrm{CO}_{2}$ (LICOR 6262) and CO (TECO 48C) measurements. The TECO and two LICORs (including a floor-level, background air monitor) were calibrated with NIST traceable standards. We continuously monitored fuel mass and stack temperature, pressure, and flow with $2 \mathrm{~s}$ resolution.

\subsection{Calculation of modified combustion efficiency and} emission factors

The excess mixing ratio of any species above background that was due to the fire at any moment was assumed to be the mixing ratio of the species measured in the stack minus the background mixing ratio, which was measured either simultaneously adjacent to the fuel bed or in the stack before and after the fire. These excess mixing ratios are designated with a capital Greek letter delta (e.g. $\Delta \mathrm{CO})$. Dividing the fire-integrated $\mathrm{CO}$ emissions $(\Delta \mathrm{CO})$ 
by the fire-integrated $\mathrm{CO}_{2}$ emissions $\left(\Delta \mathrm{CO}_{2}\right)$ yields the fire-integrated $\Delta \mathrm{CO} / \Delta \mathrm{CO}_{2}$ molar emission ratio (ER). The $\Delta \mathrm{CO} / \Delta \mathrm{CO}_{2}$ ER and the molar modified combustion efficiency (MCE, $\Delta \mathrm{CO}_{2} /\left(\Delta \mathrm{CO}_{2}+\Delta \mathrm{CO}\right)$ are used to indicate the relative amount of flaming and smoldering combustion during a fire. Higher $\triangle \mathrm{CO} / \Delta \mathrm{CO}_{2}$ or lower MCE indicates more smoldering (Ward and Radke, 1993).

For any carbonaceous fuel, a set of molar ER to $\mathrm{CO}_{2}$ that includes the major carbon-containing species (i.e. $\mathrm{CO}$, $\mathrm{CH}_{4}$, a suite of NMOC, and particle carbon) can be used to calculate emission factors (EF, $g$ of compound emitted per dry kilogram of fuel consumed) by the carbon mass balance method (Yokelson et al., 1996). This method assumes that all the burned carbon is volatilized and detected, an assumption that probably inflates the EF by 1-2\% (Andreae and Merlet, 2001). In our calculations we used the measured ash-free fuel carbon percentage (Table 1) and assumed that the particles were $60 \% \mathrm{C}$ by mass (Ferek et al., 1998).

\section{Results}

3.1 The fate of nitrogen, chlorine, and potassium in the fuel

The percentage of the fuel nitrogen that ended up in each measured, emitted nitrogen-containing trace gas is listed next in order. Ammonia $(16 \pm 8.9), \mathrm{NO}_{\mathrm{x}}(5.4 \pm 2.8), \mathrm{HCN}$ (1.3 \pm 0.6$), \quad \mathrm{CH}_{3} \mathrm{CN}(1.1 \pm 0.5)$, propanenitrile $(0.9 \pm 0.5)$, acrylonitrile $(0.5 \pm 0.3)$, and pyrrole $(0.07 \pm 0.04)$. The sum of $\mathrm{NH}_{3}+\mathrm{NO}_{\mathrm{x}}$ is within the range of previous observations and these data are potentially consistent with an accounting for all the fuel nitrogen (when $\mathrm{N}_{2}$ emissions and ash $\mathrm{N}$ are also considered) as discussed in detail by Goode et al. (1999).

For 10 of the 13 tropical fuel types for which we obtained both $\mathrm{PM}_{2.5}$ and chlorine data, approximately one third of the fuel chlorine was accounted for by the chlorine in the $\mathrm{PM}_{2.5}$ (Fig. 1a, upper (black) trend line). This is in good agreement with previous results for African fuels (Christian et al., 2003). Keene et al. (2006) also found that one third of the fuel chlorine ended up in the particles in their laboratory burns of tropical fuels (their Fig. 6b). However, 3 of 13 fuels in our current study did not adhere to this trend (Artocapus altilus, tropical composite, and Terminalia catappa). Fires with these 3 fuels had higher than average particle emissions and higher than average $\mathrm{Cl}$ concentration in the particles, but they also had very high fuel chlorine content $(>6 \mathrm{~g} / \mathrm{kg})$. The net result when these anomalous fires were included in the regression was that the particles only accounted for about $16 \%$ of the fuel chlorine (Fig. 1a, lower (red) trend line). A cause for the "low-yield" points could not be determined. We have no information on the potentially varying chemical forms of the fuel or particle chlorine. If the $\mathrm{Cl}$ in the $\mathrm{PM}_{2.5}$ was more volatile for these fires, it may have evaporated before analysis/detection. We do not know if these three fires perhaps emitted an unusual amount of large parti-
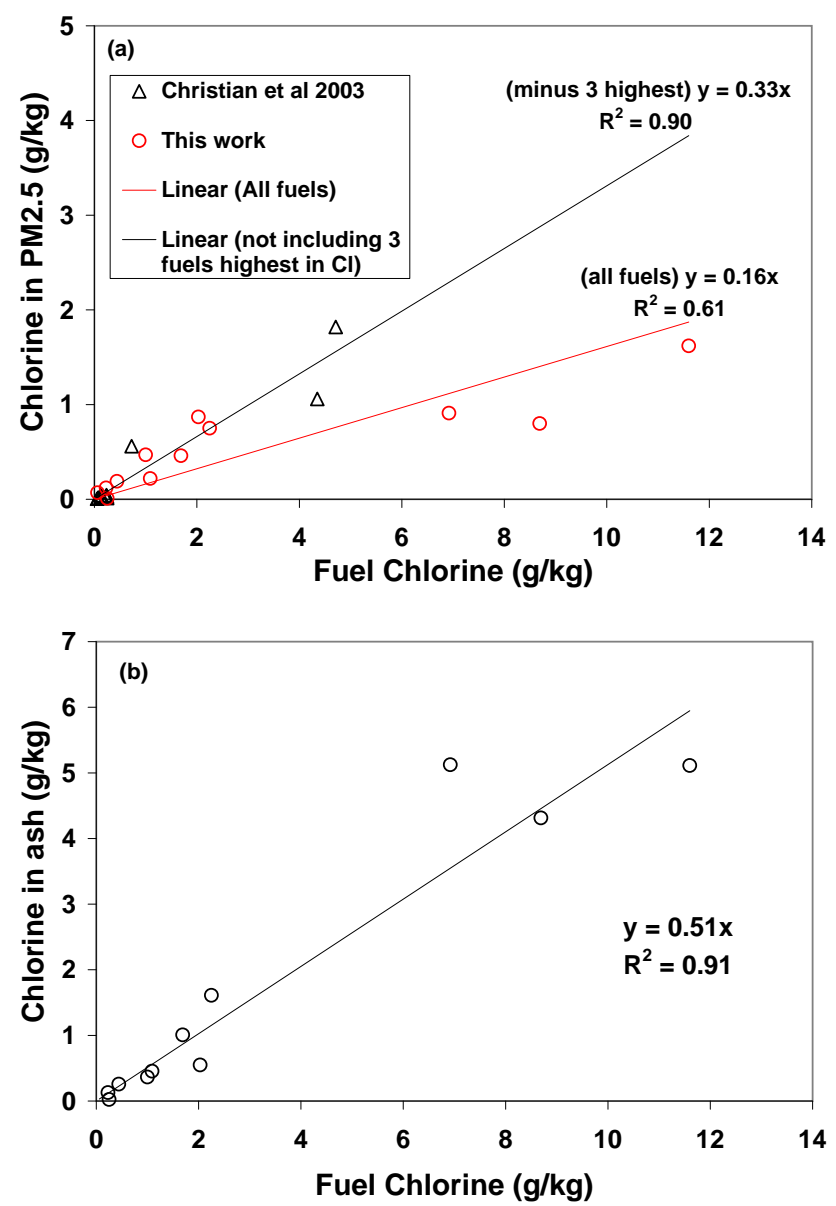

Fig. 1. Partitioning of fuel chlorine (g/kg fuel) to PM2.5 and ash ( $\mathrm{g} / \mathrm{kg}$ fuel). The upper trend line (black) in (a) is a regression fit to the data from Christian et al. (2003) and this study excluding the three fuels from this study with the highest chlorine content. The lower (red) trend line in (a) includes all the data from both studies. (b) shows all the measurements (all made in this study) of the fraction of fuel chlorine remaining in the ash.

cles that might have contained chlorine, but were intercepted by the cyclone. Re-examination of the IR spectra from these three fires did not reveal absorption features for hydrochloric acid $(\mathrm{HCl})$ or chlorinated hydrocarbons, which might have indicated a gas-phase fate for some of the fuel $\mathrm{Cl}$. We conclude that about $33 \%$ of the fuel chlorine often ends up in the particles but that important exceptions may occur.

In any case, the chlorine in the particles does not account for $67 \%$ or more of the fuel chlorine. Based on their similar results, Christian et al. (2003) hypothesized that most of the fuel chlorine remains in the ash or is emitted in unidentified trace gases. Thus, in this study we measured the yield and chlorine content of the ash and found that about one-half $(51 \%)$ of the fuel chlorine remained in the ash (Fig. 1b). With this new information, $67-84 \%$ of the fuel chlorine can 
be accounted for with the "typical" case being over $80 \%$. The remaining chlorine may be unidentified gases or volatile forms of particle chlorine. For instance, $\mathrm{HCl}$ could be initially present in the particles (thus escaping detection as a trace gas by FTIR in the stack), but then evaporate during filter storage before elemental analysis.

Treatment of the potassium data for $\mathrm{PM}_{2.5}$ in a similar fashion as Fig. 1 shows particle $\mathrm{K}$ to be relatively independent of fuel $\mathrm{K}\left(r^{2} \cong 0.4\right)$. This is expected based on the findings of Ward and Hardy (1991) who showed that the emissions of fine particle $\mathrm{K}$ were strongly associated with the proportion of flaming combustion during a fire (see their Fig. 6). Our average EF for fine particle potassium was $0.62 \pm 0.35$ ( $\mathrm{g} \mathrm{K}$ in $\mathrm{PM}_{2.5} / \mathrm{kg}$ dry fuel) obtained at an average MCE of 0.949. This is about twice the EFK $(0.29 \pm 0.22)$ reported by Andrea and Merlet (2001) for tropical forest fires, but at an average MCE of 0.906 that indicates less flaming combustion. Thus these two results are consistent with what we know about the emissions behavior for $\mathrm{K}$ and it should be clear that the mix of flaming and smoldering combustion needs to be considered when regional PM source apportionment based on $\mathrm{K}$ is performed (Ward and Hardy, 1991). Finally, we note that the average mass of $\mathrm{K}$ in $\mathrm{PM}_{2.5}$ as a percentage of the total mass of $\mathrm{K}$ in the burned fuel in this study was $4.6 \% \pm 3.1 \%$. Kauffman et al. (1998) found that $82 \pm 12 \%$ of fuel $\mathrm{K}$ remained in the ash.

3.2 Synthesis of TROFFEE laboratory, airborne, and ground-based measurements of emission factors

Table 3 presents our fire-average MCE and emission factors for each tropical fuel type burned in the laboratory. The trace gas data are segregated to indicate the source of the measurement - FTIR or PTR-MS. Consideration of this data, along with the airborne and ground-based EF measurements obtained in the field campaigns in Brazil (Yokelson et al., 2007a; Christian et al., 2007), provides an unprecedented amount of information on the relationship between the combustion characteristics and the emissions produced as well as the chemistry of these emissions. Each study offers advantages in understanding the overall picture. The airborne and ground-based measurements are of "real" fires during the peak of the 2004 biomass burning season in Brazil, but represent sampling only a part of the emissions from each fire. Explicitly, the ground-based measurements are of initiallyunlofted emissions produced by residual smoldering combustion of logs, which is reflected in their average MCE of $0.788 \pm 0.059$. A large part of these emissions is later lofted by thermal or frontal processes, but on average they may have a shorter atmospheric lifetime than the initially lofted emissions, which are also amenable to airborne sampling. The airborne measurements sample a mix of flaming and "entrained" smoldering emissions, but necessarily omit the initially unlofted emissions sampled from the ground. They have a higher average MCE of $0.910 \pm 0.021$. The laboratory experiments captured smoke over the course of the whole fire. The laboratory setting also allowed more comprehensive measurements (e.g. open-path FTIR, GC-PTR-MS, particle collection on filters, and monitoring of all the PTR-MS mass channels during the fires (as opposed to a reduced selection necessitated by the briefer times in smoke in the airborne campaign)). However, the lab fires are not authentic tropical fires. In particular, the lab fire average MCE of $0.949 \pm 0.026$ likely reflects the absence of smoldering large-diameter logs in the fuel mix. From a fuels perspective, the lab-fires primarily focused on the foliage and twigs, the ground-based measurements on large-diameter logs, and the airborne measurements on a mix of the small and large-diameter fuels.

Many earlier studies have shown plots of emission factors vs. MCE for measurements conducted on fires that were burning mostly smaller diameter fuels. For example, see the plots for airborne measurements of savanna fire EF in Yokelson et al. (2003), or lab measurements of savanna fire EF in Christian et al. (2003). In that work a high degree of correlation between EF and MCE was observed (positive correlation for compounds produced by flaming combustion and negative correlation for smoldering compounds). Also a more restricted range of MCE was observed (0.910-0.975), which probably represented the real range of fire-integrated MCE occurring in savanna fires. In discussing TROFFEE samples of deforestation fires, we will use the same "EF versus MCE" framework to probe a much wider range of conditions. In Figs. 2-4, for selected compounds, we show all the EF versus MCE from all three TROFFEE platforms on the same plot. This shows, in one view, how the emission factors are affected by a broad range of MCE and the fuel differences. All but three of the ground-based measurements (indicated by blue circles) are at an MCE below $\sim 0.85$ (mostly smoldering) and the fuel is almost exclusively large diameter logs. The lab study (red circles and "x"s) burned fine fuels and all but two of the MCE are above 0.93 (mostly flaming). The airborne points (black triangles) have intermediate MCE and burned a mix of large and fine fuels. There is more scatter in the combined TROFFEE data set than is seen in the savanna fire plots, but still good consistency between the data from the three TROFFEE platforms. For instance in Fig. 2a $\left(\mathrm{CH}_{4}\right)$ and $\mathrm{b}\left(\mathrm{CH}_{3} \mathrm{OH}\right)$, there is considerable spread in the EF from the ground-based study, but on average the ground-based EF for these smoldering compounds was higher than observed in the airborne and lab studies, which were at higher average MCE. This indicates that, for these smoldering compounds, the fuel difference associated with these different platforms did not eliminate the basic tendency for higher EF at lower MCE. A reversed pattern is shown for flaming compounds in Fig. $3 a\left(\mathrm{NO}_{\mathrm{x}}\right)$ and $\mathrm{b}\left(\mathrm{C}_{2} \mathrm{H}_{2}\right)$. Again the EF depend mainly on the amount of flaming and smoldering combustion. The one low $\mathrm{NO}_{x}$ point at high MCE was for dambo grass, which had very low fuel nitrogen (Table 1). For these four compounds (and in general), the few ground-based samples with MCE that was high enough to overlap the MCE observed in the 
Table 3. Emission factors ( $\mathrm{g} / \mathrm{kg}$ dry fuel) measured for tropical fuels burned in laboratory fires during TROFFEE. Blank field indicates not measured (usually because below detection limit).

\begin{tabular}{|c|c|c|c|c|c|c|c|c|c|c|c|c|c|c|c|c|}
\hline \multicolumn{17}{|c|}{ Fire two letter code } \\
\hline Emissions & $\mathrm{AR}$ & $\mathrm{CA}$ & $\mathrm{CC}$ & DB & DS & $\mathrm{EU}$ & FI-1 & FI-2 & MA & $\mathrm{NE}$ & PS & $\mathrm{SC}$ & $\mathrm{TC}$ & TE & Average & $\begin{array}{l}\text { Standard } \\
\text { deviation }\end{array}$ \\
\hline Carbon dioxide & 1626 & 1665 & 1668 & 1599 & 1799 & 1739 & 1850 & 1666 & 1771 & 1483 & 1640 & 1838 & 1609 & 1520 & 1677 & 111 \\
\hline MCE & 0.958 & 0.952 & 0.948 & 0.966 & 0.958 & 0.966 & 0.979 & 0.94 & 0.957 & 0.913 & 0.88 & 0.976 & 0.953 & 0.934 & 0.949 & 0.026 \\
\hline Carbon monoxide & 44.8 & 53.6 & 57.8 & 36.3 & 50.3 & 38.6 & 25.1 & 68.1 & 50.9 & 89.9 & 142.3 & 28.3 & 50.4 & 67.9 & 57.46 & 29.74 \\
\hline $\mathrm{PM}_{2.5}$ & 16.07 & 7.50 & 2.22 & 11.43 & 7.34 & 9.87 & 10.36 & 16.32 & 5.81 & & & 2.17 & 13.46 & 16.61 & 9.93 & 5.11 \\
\hline \multicolumn{17}{|l|}{ FTIR species } \\
\hline Nitric oxide & 1.164 & & 1.251 & 0.305 & 1.202 & 1.601 & 3.595 & 0.727 & 1.389 & 0.708 & 0.402 & 1.567 & 1.700 & 1.078 & 1.284 & 0.824 \\
\hline Nitrogen dioxide & 1.088 & & 0.662 & 0.418 & 0.395 & 0.371 & 0.426 & 0.975 & 0.685 & & 0.617 & 0.423 & 0.656 & 0.302 & 0.585 & 0.247 \\
\hline Methane & 3.072 & 5.577 & 4.627 & 3.030 & 3.706 & 2.935 & 0.854 & 5.251 & 2.212 & 8.428 & 3.448 & 0.933 & 3.943 & $\mathrm{c}$ & 3.818 & 1.990 \\
\hline Ethene & 1.895 & 1.394 & 1.122 & 1.035 & 1.317 & 1.417 & 0.973 & 5.214 & 1.859 & 3.588 & 1.694 & 0.629 & 1.838 & 1.705 & 1.834 & 1.194 \\
\hline Ethyne & 0.225 & & 0.240 & 0.044 & 0.109 & 0.182 & 0.428 & 1.056 & 0.282 & 0.868 & 0.275 & 0.072 & 0.328 & 0.237 & 0.334 & 0.300 \\
\hline Propene & 0.232 & & & 0.670 & 0.198 & 0.450 & & 1.297 & 0.432 & 0.687 & 0.378 & & 0.397 & 0.866 & 0.561 & 0.332 \\
\hline Formaldehyde & 0.265 & & & 0.595 & 0.147 & 0.266 & & 1.532 & & 0.629 & 0.435 & & 1.462 & 0.595 & 0.658 & 0.505 \\
\hline Methanol & 1.260 & 3.162 & 4.574 & 1.054 & 1.936 & 1.655 & 1.235 & 2.700 & 1.054 & 4.440 & 1.368 & 0.254 & 2.417 & 4.160 & 2.234 & 1.387 \\
\hline Acetic acid & 0.879 & & 3.160 & 5.658 & 1.799 & 1.705 & 2.542 & 2.772 & 1.023 & 4.856 & 1.836 & 0.959 & 3.799 & 5.923 & 2.839 & 1.749 \\
\hline Formic acid & 0.508 & & & 0.620 & 0.401 & 0.351 & & 0.371 & 0.356 & 0.929 & 0.344 & 0.128 & 1.142 & 1.238 & 0.581 & 0.363 \\
\hline Furan & 0.413 & & 0.566 & 0.391 & 0.431 & 0.464 & 0.286 & 0.570 & 0.482 & 0.834 & 0.456 & 0.505 & 0.344 & 0.683 & 0.494 & 0.145 \\
\hline Glycolaldehyde & 0.904 & & & 1.580 & 0.445 & 0.483 & & 1.765 & 0.357 & 1.578 & 0.290 & & 0.663 & 0.616 & 0.868 & 0.562 \\
\hline Isoprene & 0.339 & & 0.187 & 0.399 & 0.105 & 0.227 & 0.265 & 2.711 & 0.111 & 0.312 & 0.242 & & 0.131 & 0.571 & 0.467 & 0.719 \\
\hline Phenol & & & & 0.914 & 0.295 & 0.634 & & 1.243 & 0.845 & 2.560 & 0.258 & & 0.484 & 0.839 & 0.897 & 0.698 \\
\hline Ammonia & 5.467 & 2.419 & 2.746 & 0.135 & 4.853 & 2.509 & 2.467 & 4.257 & 2.251 & 8.026 & 1.408 & 0.559 & 7.797 & 2.548 & 3.389 & 2.412 \\
\hline Hydrogen cyanide & 0.562 & & 0.223 & 0.097 & 0.268 & 0.225 & 0.375 & 0.403 & 0.375 & 1.171 & 0.360 & 0.137 & 0.607 & 0.325 & 0.394 & 0.276 \\
\hline \multicolumn{17}{|l|}{ PTR-MS species } \\
\hline Methanol & 1.413 & 3.659 & 5.149 & 1.370 & 1.902 & 1.712 & 1.290 & 2.886 & 1.054 & 3.690 & 1.168 & 0.375 & 2.394 & 4.696 & 2.340 & 1.459 \\
\hline Acetonitrile & 0.984 & 0.455 & 0.390 & 0.107 & 0.515 & 0.348 & 0.365 & 0.773 & 0.328 & 1.003 & 0.131 & 0.096 & 1.025 & 0.455 & 0.498 & 0.326 \\
\hline Acetaldehyde & 2.105 & 1.719 & 1.963 & 2.134 & 0.932 & 0.922 & 0.701 & 3.198 & 0.881 & 3.378 & 0.655 & 0.534 & 2.525 & 2.295 & 1.710 & 0.954 \\
\hline Acrylonitrile & 0.461 & 0.359 & 0.190 & 0.042 & 0.193 & 0.164 & 0.285 & 0.554 & 0.220 & 0.623 & 0.100 & 0.068 & 0.516 & 0.242 & 0.287 & 0.187 \\
\hline Propanenitrile & 0.782 & 1.422 & & & 0.346 & 0.317 & & 0.896 & 0.336 & 0.871 & 0.238 & 0.309 & & & 0.613 & 0.403 \\
\hline Acrolein & 1.326 & 1.255 & 1.142 & 1.736 & 0.927 & 0.973 & 0.542 & 3.281 & 0.906 & 2.104 & 0.620 & 0.435 & 1.652 & 1.847 & 1.339 & 0.753 \\
\hline Acetone & 1.216 & 1.071 & 1.258 & 1.204 & 0.663 & 0.614 & 0.409 & 1.565 & 0.493 & 1.993 & 0.413 & 0.288 & 1.377 & 1.306 & 0.991 & 0.513 \\
\hline Propanal & 0.191 & 0.168 & 0.196 & 0.188 & 0.104 & 0.096 & 0.064 & 0.245 & 0.077 & 0.311 & 0.065 & 0.045 & 0.216 & 0.204 & 0.155 & 0.080 \\
\hline Pyrrole & 0.691 & 0.465 & 0.381 & 0.101 & 0.455 & 0.201 & 0.330 & 0.740 & 0.222 & 0.927 & 0.146 & 0.054 & 0.780 & 0.377 & 0.419 & 0.274 \\
\hline Furan & 0.384 & 0.323 & 0.320 & 0.450 & 0.261 & 0.238 & 0.153 & 1.468 & 0.194 & 0.579 & 0.159 & 0.070 & 0.468 & 0.620 & 0.406 & 0.346 \\
\hline Isoprene & 0.438 & 0.369 & 0.365 & 0.514 & 0.298 & 0.272 & 0.175 & 1.670 & 0.221 & 0.662 & 0.183 & 0.080 & 0.536 & 0.708 & 0.464 & 0.393 \\
\hline Crotonaldehyde & 0.244 & 0.239 & 0.254 & 0.473 & 0.170 & 0.189 & 0.117 & 0.677 & 0.155 & 0.450 & 0.114 & 0.091 & 0.285 & 0.406 & 0.276 & 0.168 \\
\hline Methacrolein & 0.160 & 0.156 & 0.166 & 0.310 & 0.111 & 0.125 & 0.076 & 0.442 & 0.102 & 0.295 & 0.075 & 0.059 & 0.186 & 0.265 & 0.181 & 0.110 \\
\hline Methyl vinyl ketone & 0.404 & 0.394 & 0.421 & 0.783 & 0.280 & 0.314 & 0.194 & 1.120 & 0.259 & 0.744 & 0.185 & 0.151 & 0.471 & 0.671 & 0.456 & 0.279 \\
\hline Methyl propanal & 0.285 & 0.309 & 0.333 & 0.508 & 0.154 & 0.126 & 0.116 & 0.404 & 0.111 & 0.513 & 0.099 & 0.087 & 0.404 & 0.402 & 0.275 & 0.157 \\
\hline Methyl ethyl ketone & 0.809 & 0.880 & 0.950 & 1.447 & 0.438 & 0.358 & 0.330 & 1.150 & 0.316 & 1.462 & 0.285 & 0.248 & 1.150 & 1.142 & 0.783 & 0.447 \\
\hline Acetol + Methyl acetate & 1.385 & 1.984 & 2.904 & 4.559 & 0.667 & 0.923 & 0.309 & 2.627 & 0.704 & 3.494 & 0.865 & 0.361 & 1.597 & 2.980 & 1.811 & 1.314 \\
\hline Benzene & 0.624 & 0.563 & 0.461 & 0.221 & 0.508 & 0.533 & 0.423 & 1.762 & 0.678 & 1.240 & 0.622 & 0.207 & 0.644 & 0.621 & 0.650 & 0.402 \\
\hline C6 Carbonyls & 0.462 & 0.639 & 0.580 & 0.870 & 0.432 & 0.659 & 0.278 & 1.354 & 0.329 & 0.948 & 0.366 & 0.110 & 0.630 & 0.924 & 0.613 & 0.327 \\
\hline 2-methyl furan & 0.096 & 0.129 & 0.130 & 0.160 & 0.080 & 0.069 & 0.039 & 0.185 & 0.052 & 0.216 & 0.046 & 0.020 & 0.114 & 0.199 & 0.110 & 0.063 \\
\hline 3-methyl furan & 0.670 & 0.900 & 0.908 & 1.117 & 0.561 & 0.480 & 0.271 & 1.292 & 0.368 & 1.517 & 0.325 & 0.142 & 0.796 & 1.388 & 0.767 & 0.439 \\
\hline 2,3-butanedione & 1.031 & 1.441 & 1.918 & 2.900 & 0.676 & 0.759 & 0.394 & 1.662 & 0.487 & 2.362 & 0.542 & 0.304 & 1.497 & 2.128 & 1.293 & 0.820 \\
\hline 2-pentanone & 0.106 & 0.153 & 0.206 & 0.316 & 0.071 & 0.081 & 0.041 & 0.174 & 0.050 & 0.249 & 0.057 & 0.032 & 0.158 & 0.227 & 0.137 & 0.089 \\
\hline 3-pentanone & 0.047 & 0.068 & 0.092 & 0.141 & 0.031 & 0.036 & 0.018 & 0.077 & 0.022 & 0.110 & 0.026 & 0.014 & 0.070 & 0.102 & 0.061 & 0.040 \\
\hline Toluene & 0.740 & 0.474 & 0.443 & 0.255 & 0.525 & 0.506 & 0.302 & 1.226 & 0.350 & 1.093 & 0.341 & 0.120 & 0.816 & 0.578 & 0.555 & 0.316 \\
\hline Phenol & 0.766 & 0.681 & 0.621 & 0.852 & 0.614 & 0.563 & 0.342 & 1.227 & 0.841 & 1.428 & 0.435 & 0.165 & 0.796 & 0.855 & 0.728 & 0.328 \\
\hline Furaldehydes & 0.250 & 0.410 & 0.405 & 0.816 & 0.298 & 0.301 & 0.133 & 0.492 & 0.171 & 0.660 & 0.181 & 0.149 & 0.335 & 1.171 & 0.412 & 0.294 \\
\hline Substituted furans & 0.943 & 1.541 & 1.519 & 3.063 & 1.126 & 1.128 & 0.501 & 1.848 & 0.646 & 2.479 & 0.678 & 0.557 & 1.262 & 4.401 & 1.549 & 1.104 \\
\hline Ethyl benzene & 0.219 & 0.177 & 0.149 & 0.078 & 0.147 & 0.145 & 0.117 & 0.469 & 0.154 & 0.334 & 0.135 & 0.060 & 0.217 & 0.180 & 0.184 & 0.105 \\
\hline Xylenes & 0.477 & 0.355 & 0.307 & 0.170 & 0.274 & 0.259 & 0.211 & 0.814 & 0.222 & 0.579 & 0.183 & 0.115 & 0.463 & 0.342 & 0.341 & 0.189 \\
\hline
\end{tabular}

other studies have EF that fit in remarkably well. The lowest MCE fire from the lab study (Ps, Tables 1 and 3) had EF that seemed to be possible outliers when looking only at the lab data, but these EF fit well into the full range established by the other studies (Figs. 2 and 3). Also apparent, in the methanol plot (Fig. 2b), is the excellent agreement between the open-path FTIR and the PTR-MS for this compound.
Our combined TROFFEE data also reveal a few compounds that previously showed strong negative correlation with MCE (classic "smoldering compounds") for which the negative correlation is weakened or absent in the TROFFEE "coupled" data set. A good example of this is $\mathrm{C}_{2} \mathrm{H}_{4}$. First, in Fig. 4a, we show the highly-correlated $\mathrm{EFC}_{2} \mathrm{H}_{4}$ vs. MCE for airborne and lab samples of African savanna fires from Yokelson et al. (2003) and Christian et al. (2003). Then 

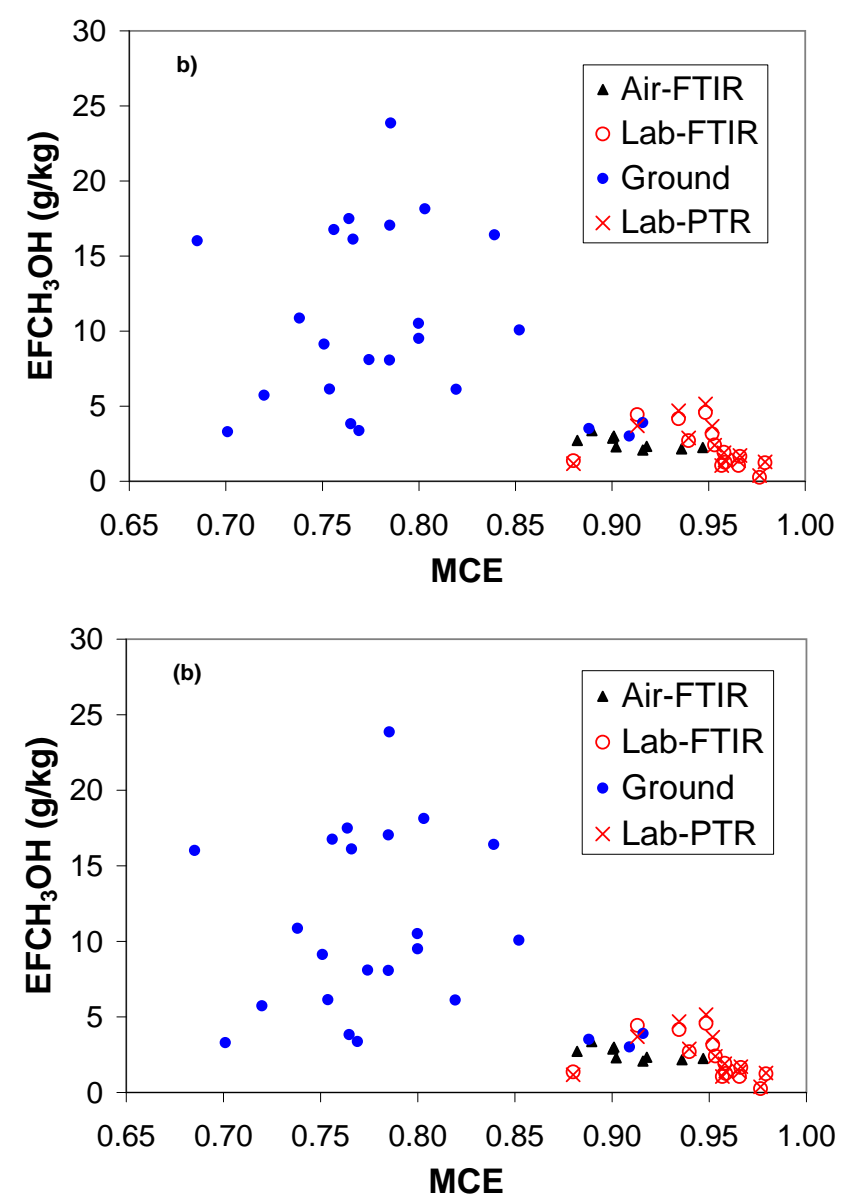

Fig. 2. Presentation of all the emission factors measured during TROFFEE from ground-based, airborne, and laboratory platforms for $\mathrm{CH}_{4}$ (a) and $\mathrm{CH}_{3} \mathrm{OH}$ (b). Despite differences in fuels between the experiments, these compounds show a consistent trend of increasing emissions with decreasing MCE indicating fuelindependent production largely by smoldering combustion. There is also a large range in the EF observed (factor of $\sim 20$ ).

Fig. $4 \mathrm{~b}$ shows all the TROFFEE $\mathrm{C}_{2} \mathrm{H}_{4}$ data. In Fig. $4 \mathrm{~b}$ there is still good agreement between the three platforms in the MCE range where they overlap (MCE 0.9), but there is not a strong indication that the average EF at low MCE is higher than the average EF at high MCE. Thus, the classic smoldering compound pattern breaks down, even though the pattern is apparent when only the lab, or only the airborne data, is considered. One possible explanation is that the smoldering logs sampled in the ground-based study (and to a lesser extent in the airborne study) emit less $\mathrm{C}_{2} \mathrm{H}_{4}$ per unit mass than smoldering foliar fuels. Another possibility is that $\mathrm{C}_{2} \mathrm{H}_{4}$ is produced by both direct pyrolysis of biomass and incomplete oxidation in flames as may also be the case for $\mathrm{C}_{2} \mathrm{H}_{2}$. Another compound which may belong in this inconclusive category is $\mathrm{HCHO}$.
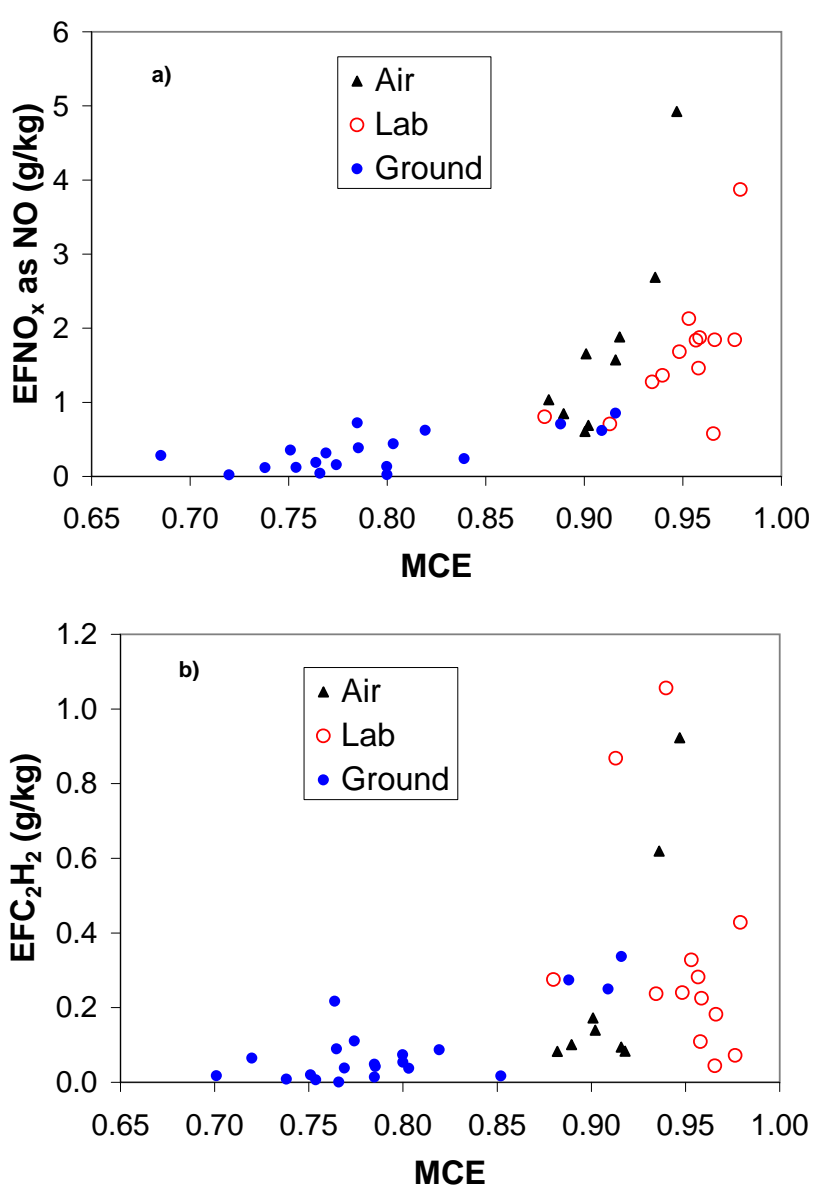

Fig. 3. Presentation of all the emission factors measured during TROFFEE from ground-based, airborne, and laboratory platforms for $\mathrm{NO}_{\mathrm{x}}(\mathbf{a})$ and $\mathrm{C}_{2} \mathrm{H}_{2}$ (b). Despite differences in fuels between the experiments, these compounds show a consistent trend of increasing emissions with increasing MCE indicating production mainly by weakly fuel-dependent flaming combustion. There is also a large range in the EF observed (factor of $\sim 20$ ).

Finally, a few compounds have little correlation with MCE in both this and earlier work. Chief among these are HCN (Fig. 4c), acetonitrile (Fig. 4d), and formic acid. The lack of a strong dependence on MCE can aid in the use of HCN and acetonitrile as biomass burning tracers. Specifically, knowing the MCE of the fire source is not that important (as opposed to the case when using K). However, the EF for HCN and acetonitrile are quite variable for tropical forest fires and significantly different, highly variable emissions of these compounds are produced by other global types of biomass burning. This may be related to fuel nitrogen differences (Yokelson et al. 2007a, b). For the laboratory fires we have total fuel $\mathrm{N}$ data and can examine the dependence of the $\mathrm{EF}$ for $\mathrm{N}$-compounds on total fuel $\mathrm{N}$. We start by noting that, for the lab fires, the standard deviation in the EF divided by 

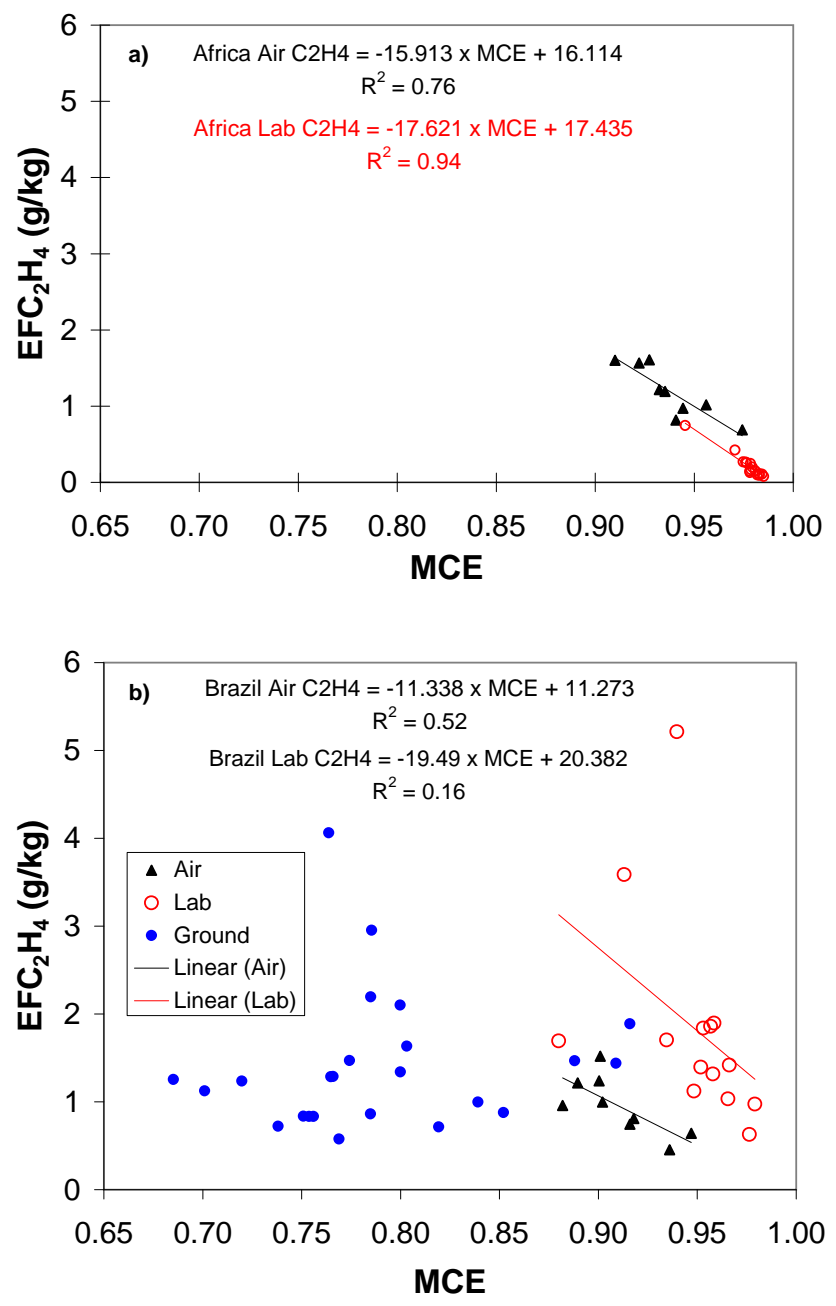

Fig. 4. (a) The relevant range of fire-integrated MCE for savanna fires is about 0.90-0.98. For $\mathrm{C}_{2} \mathrm{H}_{4}$, over this range, the $\mathrm{EF}$ from airborne measurements of African savanna fires and the lab EF measured using savanna fuels are in good agreement with each other and highly correlated with MCE. (b) The agreement between the lab and air and the correlation with MCE decreases for tropical forest fire EF. Including the ground-based field data indicates that $\mathrm{EFC}_{2} \mathrm{H}_{4}$ may be fuel dependent (lower from woody material than foliage) and/or not uniquely identified with either flaming or smoldering combustion.

the mean $\mathrm{EF}$ is $0.69 \pm 0.03$ for $\mathrm{HCN}, \mathrm{CH}_{3} \mathrm{CN}$, and $\mathrm{NH}_{3}$. If we divide each $\mathrm{EF}$ by the total fuel $\mathrm{N}$, this ratio decreases to $0.51 \pm 0.04$. Thus there is a significant, almost, $30 \%$ decrease in variability when normalizing these EF by total fuel $\mathrm{N}$. The fact that considerable variability remains may indicate that the emission of these $\mathrm{N}$ compounds may depend less on total fuel $\mathrm{N}$ than they do on the fuel content of specific $\mathrm{N}$-containing molecules that naturally occur in quite variable amounts.
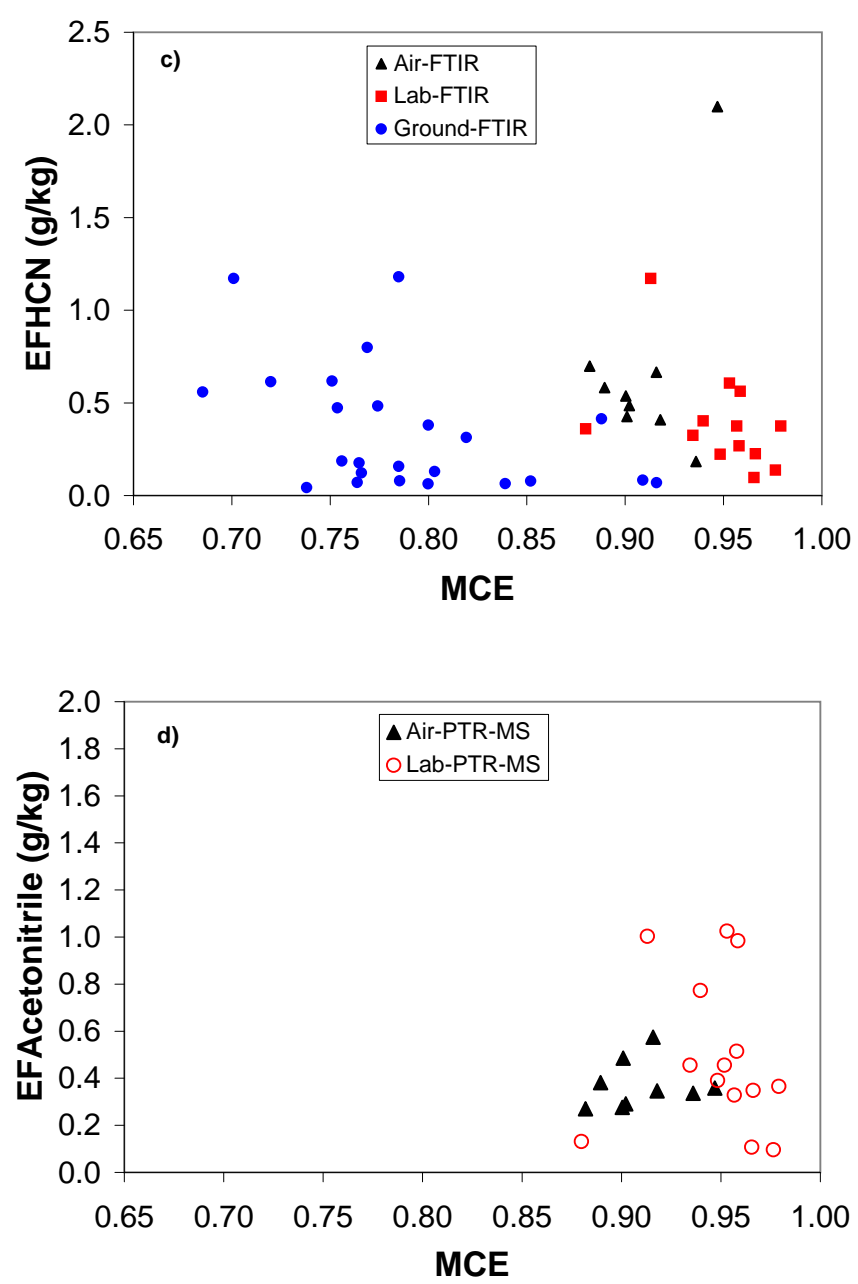

Fig. 4. Continued. The EF for $\mathrm{HCN}$ or acetonitrile did not show a strong dependence on MCE over the range of measurements obtained in TROFFEE. Thus, our study-average EF likely represent both the lofted and the initially unlofted emissions produced by tropical deforestation fires. Since these compounds are thought to be emitted mainly by biomass burning and the EF is relatively MCE-independent, the average EF can be used for source apportionment without great concern that the often-undersampled initially-unlofted emissions actually contribute a significantly different EF. On the other hand, the large variability in EF at all MCE limits the precision of estimates.

In theory, capturing our full measured range of EF versus MCE would significantly enhance the accuracy of emissions estimates and the input for local-global models. For instance, the average $\mathrm{EFCH}_{4}$ varies by about a factor of 20 over the MCE range sampled during TROFFEE. Unfortunately, the prospects for measuring the MCE of fires from space as they occur are not good as it would require very accurate quantification of small $\mathrm{CO}_{2}$ enhancements against a large background and a very precise spatial scale. We cannot even be confident of seasonal trends in average MCE for 
fires in the major, global biomass burning areas for reasons discussed in Yokelson et al. (2007a), Korontzi et al. (2003), and Hoffa et al. (1999). For example, in TROFFEE we have evidence that the MCE of lofted plumes seems to increase as the dry season progresses, but we suspect that the amount of low-MCE residual smoldering combustion may also increase as the large diameter fuels dry out (Yokelson et al., 2007a). Thus, for now, we attempt to estimate one MCE and a set of associated EF for all the detected emissions that are intended for application to the whole dry season. We provide this for the two main types of fires in the Brazilian Amazon: primary deforestation fires and pasture maintenance fires - each of which are thought to consume about $240 \mathrm{Tg}$ of biomass annually in the region (Yokelson et al., 2007a). We hypothesize that our EF for Brazil are also reasonable for these fire types in the other tropical forests around the globe. However, we note that pasture fires are thought to be far less significant relative to primary deforestation fires in the other major tropical forest areas of the globe.

Our derivation of recommended EF values draws on ground-based measurements of the amount of fuel consumed by the plume-forming and residual-smoldering stages of real fires in Brazil. As discussed in detail by Christian et al. (2007) and references therein, the available evidence suggests that for tropical deforestation fires about $5 \%$ of the fuel consumption is by residual smoldering and $95 \%$ of the consumption is during the convective plume forming phase of the fire. On the other hand, for pasture maintenance fires, it seems likely that about $40 \%$ of the fuel consumption is by residual smoldering with the balance $(60 \%)$ feeding into the initially-lofted emissions. Thus, for the 14 compounds for which we have both airborne and ground-based EF for real fires in Brazil, we simply take an average of the airborne and ground-based EF weighted according to the above percentages. (An explicit formula for this straightforward process has been given elsewhere (Bertschi et al., 2003a; Christian et al., 2007)). The one pasture fire sampled from the air had lofted emissions that were not significantly different (statistically) than the other fires so we used the study-average airborne values for both fire types. Table 4 shows the EF for deforestation and pasture maintenance fires calculated in this way. One important result of this approach is that the average fire-integrated MCE for primary deforestation fires is calculated to be 0.904 and the average fire-integrated MCE for pasture fires is 0.861 .

Because no ground-based sampling of fires was done in TROFFEE with filters, PTR-MS, or GC, there are 27 compounds and PM for which we have EF measurements only from the air and lab. For these compounds we need a method to start with lab and/or airborne data and derive EF that represent the total emissions from authentic primary deforestation and pasture fires. Several approaches were tested by applying them to the compounds for which we had both ground and airborne field data and then calculating how well the predictions agreed with the weighted average values obtained as described above. For instance, Christian et al. (2003) found that using the lab-based EF vs. MCE equation at the fieldaverage MCE returned EF that agreed well with the field average EF for savanna fires. However, for TROFFEE, the lab equations tended to significantly overpredict the field measured $\mathrm{EF}$ (factor of $\sim 2$ on average). Using the airborne EF vs. MCE relation to calculate $\mathrm{EF}$ at the MCE for pasture fires worked well for some compounds, but not for others (e.g. formaldehyde and acetic acid) and the typical error was $65-70 \%$ of the target value. Predictions with smaller error (averaging 10-40\% of the target) were eventually obtained from a simpler approach. We found that for smoldering compounds not containing nitrogen the following relations were observed:

$\mathrm{EF}$ (for primary deforestation fires) =

$\mathrm{EF}$ (airborne average) $\times 1.12 \pm 0.11$

$\mathrm{EF}$ (for pasture maintenance fires) $=$

$\mathrm{EF}$ (airborne average) $\times 2.00 \pm 0.90$

Equation (1) suggests that a $12 \%$ increase of the airborne average EF for smoldering compounds is appropriate for primary deforestation fires, which seems not too controversial as this involves a small increase to compensate for a small amount of unsampled smoldering emissions. Equation (2) makes the bolder suggestion that the average airborne EF (for smoldering compounds) should be doubled to obtain a fire-integrated value appropriate for pasture fires. This prediction is close for some of the "standard" compounds (e.g. $\left.\mathrm{CH}_{4}, 1.81 ; \mathrm{C}_{3} \mathrm{H}_{6}, 1.87 ; \mathrm{CH}_{3} \mathrm{OH}, 2.21\right)$. However, it's further off for other compounds such as $\mathrm{HCOOH}(0.89), \mathrm{CH}_{3} \mathrm{COOH}$ (2.90), furan (3.14), and phenol (3.41). Thus, estimates for pasture fires based on this formula have considerable uncertainty, but are probably a step in the right direction for most compounds. The EF estimated using Eqs. (1) and (2) are shown as a second group of EF in Table 4.

The predictions for pasture fires based on Eq. (2) are perhaps most intriguing for particles. The airborne average for $\mathrm{PM}_{10}$ was $17.8 \pm 4.1$. This EF was already larger than values obtained in previous studies as discussed by Yokelson et al. (2007a): possibly due partly to a trend toward larger fires in the Amazon. Doubling this value, as suggested by Eq. (3), to obtain an EF for pasture fires, then implies a fire-integrated $\mathrm{EFPM}_{10}$ of $35.6 \mathrm{~g} / \mathrm{kg}$, which is well above the range usually recommended for various types of biomass burning (Andreae and Merlet, 2001). Alternate methods to estimate an EF for $\mathrm{PM}$ at the pasture fire MCE of 0.861 can also be tried. For instance, using the EF versus MCE relationship from the airborne data returns an $\mathrm{EFPM}_{10}$ of $23.4 \mathrm{~g} / \mathrm{kg}$ at the pasture fire MCE of 0.861. On the other hand, using the lab based EF vs. MCE for $\mathrm{PM}_{2.5}$ returns a pasture fire $\mathrm{EFPM}_{2.5}$ of $27.1 \mathrm{~g} / \mathrm{kg}$. If this EFPM 2.5 is increased by $20 \%$ to account for the typical difference between $\mathrm{PM}_{2.5}$ and $\mathrm{PM}_{10}$ (Artaxo et al., 1998; Andreae and Merlet, 2001) we obtain an EFPM 10 of $33.9 \mathrm{~g} / \mathrm{kg}$, 
Table 4. Emission factors (EF) for primary tropical deforestation and pasture maintenance fires.

\begin{tabular}{|c|c|c|c|c|c|c|c|}
\hline \multirow[b]{2}{*}{ Species (TROFFEE data) } & \multirow[b]{2}{*}{$\begin{array}{c}\text { Ground avg } \\
\mathrm{g} / \mathrm{kg}\end{array}$} & \multirow[b]{2}{*}{$\begin{array}{c}\text { Air avg } \\
\mathrm{g} / \mathrm{kg}\end{array}$} & \multirow[b]{2}{*}{$\begin{array}{c}\mathrm{Lab} \mathrm{avg}^{\mathrm{c}} \\
\mathrm{g} / \mathrm{kg}\end{array}$} & \multicolumn{2}{|c|}{ Recommended EF } & \multicolumn{2}{|c|}{ Annual averages } \\
\hline & & & & $\begin{array}{l}\text { Primary } \\
\text { Deforest. } \\
\text { method }^{\mathrm{d}} \\
\mathrm{g} / \mathrm{kg}\end{array}$ & $\begin{array}{l}\text { Pasture } \\
\text { Maint. } \\
\text { method } \\
\text { g/kg }\end{array}$ & $\begin{array}{l}\text { Amazon } \\
\text { Region }^{\mathrm{f}} \\
\mathrm{Tg}\end{array}$ & $\begin{array}{c}\text { Global Trop. } \\
\text { Deforest. } \\
\text { Tg }\end{array}$ \\
\hline $\mathrm{CO}_{2}$ & 1343 & 1615 & 1677 & 1601 & 1506 & 746 & 2130 \\
\hline $\mathrm{CO}$ & 228.8 & 101.4 & 57.5 & 107.8 & 152.4 & 62.4 & 143.4 \\
\hline MCE & 0.788 & 0.910 & 0.949 & 0.904 & 0.861 & & \\
\hline $\mathrm{NO}_{x}$ as NO & 0.33 & 1.77 & 1.67 & 1.70 & 1.19 & 0.69 & 2.25 \\
\hline $\mathrm{CH}_{4}$ & 17.12 & 5.68 & 3.82 & 6.25 & 10.26 & 3.96 & 8.32 \\
\hline $\mathrm{C}_{2} \mathrm{H}_{4}$ & 1.42 & 0.95 & 1.83 & 0.98 & 1.14 & 0.51 & 1.30 \\
\hline $\mathrm{C}_{2} \mathrm{H}_{2}$ & 0.09 & 0.28 & 0.33 & 0.27 & 0.20 & 0.11 & 0.36 \\
\hline $\mathrm{C}_{3} \mathrm{H}_{6}$ & 1.43 & 0.45 & 0.56 & 0.50 & 0.84 & 0.32 & 0.66 \\
\hline $\mathrm{HCOOH}$ & 0.26 & 0.59 & 0.58 & 0.57 & 0.46 & 0.25 & 0.76 \\
\hline $\mathrm{CH}_{3} \mathrm{COOH}$ & 19.73 & 3.43 & 2.84 & 4.25 & 9.95 & 3.41 & 5.65 \\
\hline $\mathrm{HCHO}$ & 1.88 & 1.66 & 0.66 & 1.67 & 1.75 & 0.82 & 2.23 \\
\hline $\mathrm{CH}_{3} \mathrm{OH}$ & 10.30 & 2.57 & 2.29 & 2.95 & 5.66 & 2.07 & 3.93 \\
\hline Phenol & 2.42 & 0.34 & 0.81 & 0.45 & 1.17 & 0.39 & 0.60 \\
\hline Acetol + Methyl acetate & 8.89 & 0.72 & 1.81 & 1.13 & 3.99 & 1.23 & 1.50 \\
\hline Furan & 2.08 & 0.33 & 0.45 & 0.41 & 1.03 & 0.35 & 0.55 \\
\hline $\mathrm{NH}_{3}$ & 1.64 & 1.08 & 3.39 & 1.10 & 1.30 & 0.58 & 1.47 \\
\hline $\mathrm{HCN}$ & 0.35 & 0.68 & 0.39 & 0.66 & 0.54 & 0.29 & 0.88 \\
\hline Species with no ground data & & & & method $^{\mathrm{h}}$ & method $^{\mathrm{i}}$ & & \\
\hline $\mathrm{C}_{2} \mathrm{H}_{6}$ & & 0.90 & & 1.01 & 1.80 & 0.67 & 1.34 \\
\hline Acetonitrile & & 0.37 & 0.5 & 0.41 & 0.74 & 0.28 & 0.55 \\
\hline Acetaldehyde & & 1.38 & 1.71 & 1.55 & 2.77 & 1.04 & 2.06 \\
\hline Acrylonitrile & & 0.04 & 0.29 & 0.04 & 0.08 & 0.03 & 0.06 \\
\hline Acrolein & & 0.58 & 1.34 & 0.65 & 1.16 & 0.43 & 0.86 \\
\hline Acetone & & 0.57 & 0.99 & 0.63 & 1.13 & 0.42 & 0.84 \\
\hline Propanal & & 0.09 & 0.16 & 0.10 & 0.18 & 0.07 & 0.13 \\
\hline Pyrrole & & 0.11 & 0.42 & 0.12 & 0.22 & 0.08 & 0.17 \\
\hline Isoprene & & 0.37 & 0.46 & 0.42 & 0.75 & 0.28 & 0.56 \\
\hline Methyl vinyl ketone & & 0.35 & 0.46 & 0.39 & 0.70 & 0.26 & 0.52 \\
\hline Methacrolein & & 0.14 & 0.18 & 0.15 & 0.28 & 0.10 & 0.21 \\
\hline Crotonaldehyde & & 0.21 & 0.28 & 0.24 & 0.42 & 0.16 & 0.31 \\
\hline Methyl ethyl ketone & & 0.45 & 0.78 & 0.50 & 0.90 & 0.34 & 0.67 \\
\hline Methyl propanal & & 0.16 & 0.28 & 0.18 & 0.32 & 0.12 & 0.24 \\
\hline Benzene & & 0.26 & 0.65 & 0.30 & 0.53 & 0.20 & 0.39 \\
\hline C6 Carbonyls & & 0.21 & 0.61 & 0.24 & 0.42 & 0.16 & 0.32 \\
\hline 3-methylfuran & & 0.53 & 0.77 & 0.59 & 1.05 & 0.39 & 0.79 \\
\hline 2-methylfuran & & 0.08 & 0.11 & 0.08 & 0.15 & 0.06 & 0.11 \\
\hline Hexanal & & 0.01 & & 0.01 & 0.03 & 0.01 & 0.02 \\
\hline 2,3 butanedione & & 0.66 & 1.29 & 0.73 & 1.31 & 0.49 & 0.98 \\
\hline 2-pentanone & & 0.07 & 0.14 & 0.08 & 0.14 & 0.05 & 0.10 \\
\hline 3-pentanone & & 0.03 & 0.06 & 0.03 & 0.06 & 0.02 & 0.05 \\
\hline Toluene & & 0.20 & 0.56 & 0.22 & 0.39 & 0.15 & 0.29 \\
\hline Other substituted furans & & 1.08 & 1.55 & 1.21 & 2.17 & 0.81 & 1.61 \\
\hline Furaldehydes & & 0.26 & 0.41 & 0.29 & 0.51 & 0.19 & 0.38 \\
\hline Xylenes & & 0.13 & 0.34 & 0.14 & 0.26 & 0.10 & 0.19 \\
\hline Ethylbenzene & & 0.08 & 0.18 & 0.08 & 0.15 & 0.06 & 0.11 \\
\hline
\end{tabular}


Table 4. Continued.

\begin{tabular}{|c|c|c|c|c|c|c|c|}
\hline Species (cont) & $\begin{array}{c}\text { Ground EF } \\
\text { g/kg }\end{array}$ & $\begin{array}{l}\text { Air EF } \\
\mathrm{g} / \mathrm{kg}\end{array}$ & $\begin{array}{l}\text { Lab EF } \\
\text { g/kg }\end{array}$ & $\begin{array}{c}\text { Primary EF } \\
\text { g/kg }\end{array}$ & $\begin{array}{c}\text { Pasture EF } \\
\text { g/kg }\end{array}$ & $\begin{array}{l}\text { Amazon } \\
\text { Tg }\end{array}$ & $\begin{array}{c}\text { Global Trop. } \\
\text { Forest } \\
\text { Tg }\end{array}$ \\
\hline \multicolumn{8}{|l|}{ Other TROFFEE species $\mathrm{j}$} \\
\hline $\mathrm{PM}_{10}$ & & 17.83 & & 18.5 & 23.4 & 10.06 & 24.61 \\
\hline $\mathrm{PM}_{2.5}$ & & & 9.93 & 14.8 & 18.7 & 8.04 & 19.68 \\
\hline Glycolaldehyde & & & 0.87 & 1.32 & 3.09 & 1.06 & 1.75 \\
\hline Propanenitrile & & & 0.61 & 0.09 & 0.17 & 0.06 & 0.12 \\
\hline $\mathrm{OCS}^{\mathrm{k}}$ & & 0.0247 & & & & 0.0119 & 0.0329 \\
\hline $\mathrm{DMS}^{\mathrm{k}}$ & & 0.0022 & & & & 0.0011 & 0.0030 \\
\hline $\mathrm{CFC} 12^{\mathrm{k}}$ & & 0.0028 & & & & 0.0014 & 0.0037 \\
\hline $\mathrm{MeONO}_{2}^{\mathrm{k}}$ & & 0.0163 & & & & 0.0078 & 0.0217 \\
\hline $\mathrm{EtONO}_{2}^{\mathrm{k}}$ & & 0.0057 & & & & 0.0027 & 0.0076 \\
\hline $\mathrm{i}-\mathrm{PrONO}{ }_{2}^{\mathrm{k}}$ & & 0.0010 & & & & 0.0005 & 0.0013 \\
\hline $\mathrm{n}-\mathrm{PrONO}{ }_{2}^{\mathrm{k}}$ & & 0.0003 & & & & 0.0002 & 0.0005 \\
\hline $2-\mathrm{BuONO}_{2}^{k}$ & & 0.0006 & & & & 0.0003 & 0.0008 \\
\hline 1-Butene $\mathrm{k}^{2}$ & & 0.0200 & & & & 0.0096 & 0.0266 \\
\hline trans-2-Butene ${ }^{k}$ & & 0.0161 & & & & 0.0077 & 0.0214 \\
\hline cis-2-Butene ${ }^{k}$ & & 0.0202 & & & & 0.0097 & 0.0268 \\
\hline Total identified NMOC & & & & 25.77 & 48.70 & 17.87 & 34.28 \\
\hline \multicolumn{8}{|l|}{ Other major species 1} \\
\hline $\mathrm{H}_{2}$ & & & & 3.8 & & 1.82 & 5.05 \\
\hline $\mathrm{N}_{2}$ & & & & 3.1 & & 1.49 & 4.12 \\
\hline $\mathrm{SO}_{2}$ & & & & 0.57 & & 0.27 & 0.76 \\
\hline
\end{tabular}

a From Christian et al. (2007).

b From Yokelson et al. (2007a).

c Average of FTIR and PTR-MS if measured by both.

$\mathrm{d}$ Assuming 5\% of ground average and $95 \%$ of airborne average (Christian et al., 2007).

e Assuming $40 \%$ of ground average and $60 \%$ of airborne average (Christian et al., 2007).

${ }^{\mathrm{f}}$ Assuming $240 \mathrm{Tg}$ biomass burned in each fire type (Yokelson et al., 2007a).

g Assuming 1330 Tg biomass burned (Andreae and Merlet, 2001) coupled with TROFFEE primary deforestation emission factors.

$\mathrm{h}$ Computed from 1.12 times air average (see Sect. 3.2).

${ }^{\mathrm{i}}$ Computed from 2.00 times air average (see Sect. 3.2).

j See Sect. 3.2 for computation method.

${ }^{\mathrm{k}}$ Based on one canister sample of smoke from the 5 September planned fire (Yokelson et al., 2007a).

${ }^{1}$ From Andreae and Merlet (2001).

which agrees remarkably well with the prediction of Eq. (2). At this point it is worth noting that our airborne $\mathrm{PM}_{10}$ measurements by nephelometer are reasonably consistent with our lab-based gravimetric measurements of $\mathrm{PM}_{2.5}$ as shown in Fig. 5.

We also have gravimetric $\mathrm{EFPM}_{2.5}$ measurements for temperate-forest woody materials from previous laboratory experiments that are relevant to this discussion. Christian et al. (2003) reported two gravimetric spot-measurements of a smoldering (hardwood) cottonwood log in their Table 2. The EFPM 2.5 for one Teflon filter was $20.9 \mathrm{~g} / \mathrm{kg}$. A second (quartz filter) sample showed $24.48 \mathrm{gC} / \mathrm{kg}$. Since biomass burning particles are typically $60 \% \mathrm{C}$, this second sample could imply the "spot" $\mathrm{EFPM}_{2.5}$ was $41 \mathrm{~g} / \mathrm{kg}$. Bertschi et al. (2003a) made 12 gravimetric spot-measurements of the "instantaneous" $\mathrm{EFPM}_{2.5}$ during a lab fire that burned first a woody (softwood) stump and then duff and organic soil (Fig. 6). The stump was ignited on top and the first 6 filter samples taken reflected consumption of the stump. The EFPM 2.5 for these samples ranged from $20.5-109 \mathrm{~g} / \mathrm{kg}$ with an average (weighted by the fuel consumption data) of $30.6 \mathrm{~g} / \mathrm{kg}$. (The $\mathrm{EFPM}_{2.5}$ for smoldering duff was only $2.95 \mathrm{~g} / \mathrm{kg}$ and the fire average reported by Bertschi et al. was $15.8 \mathrm{~g} / \mathrm{kg}$.) If we increment the average $\mathrm{EFPM}_{2.5}$ for 


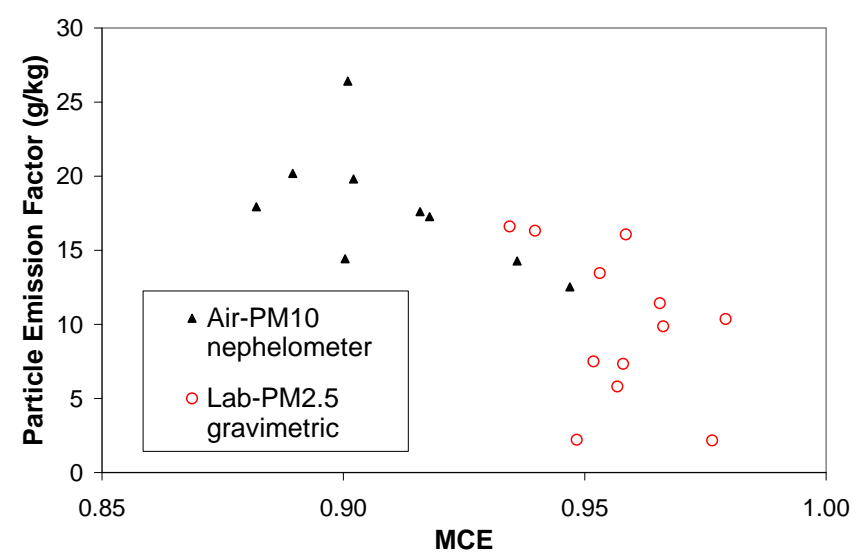

Fig. 5. The gravimetric $\mathrm{PM}_{2.5}$ measurements in the lab and the nephelometer based $\mathrm{PM}_{10}$ measurements from the airborne campaign are consistent with each other. Both data sets indicate that an emission factor for fine particles in the range of $20-30 \mathrm{~g} / \mathrm{kg}$ would be reasonable at a fire integrated MCE of 0.861 , which is appropriate for pasture maintenance fires (Sect. 3.2).

the stump by $20 \%$ we obtain an $\mathrm{EFPM}_{10}$ for unlofted smoldering of woody material of $38.3 \mathrm{~g} / \mathrm{kg}$. Taking $40 \%$ of this value and $60 \%$ of the airborne average of $17.8 \mathrm{~g} / \mathrm{kg}$ yields a fire-integrated $\mathrm{EFPM}_{10}$ for pasture fires of $26.0 \mathrm{~g} / \mathrm{kg}$. This last value agrees reasonably well with the $\mathrm{EFPM}_{10}$ obtained at the pasture fire MCE from the airborne $\mathrm{PM}_{10}$ measurements $(23.4 \mathrm{~g} / \mathrm{kg})$. Thus, we take $23.4 \mathrm{~g} / \mathrm{kg}$ and $18.7 \mathrm{~g} / \mathrm{kg}$ (80\% of the $\mathrm{PM}_{10}$ ) as conservative estimates for EFPM 10 and $\mathrm{EFPM}_{2.5}$ for pasture fires, respectively. The analogous values for primary deforestation fires would be 18.5 and $14.8 \mathrm{~g} / \mathrm{kg}$.

Several summary statements are in order. In general, our TROFFEE EFPM are higher than in previous studies (9$11 \mathrm{~g} / \mathrm{kg} \mathrm{PM}_{2.5}$, Ferek et al., 1998; Andreae and Merlet 2001). This implies that much more primary particulate matter is produced by tropical deforestation than previously assumed. For example, assuming equal amounts of biomass consumption by primary deforestation fires and pasture maintenance fires (Kauffman et al., 1998), we obtain an Amazon-average $\mathrm{EFPM}_{2.5}$ of $16.8 \mathrm{~g} / \mathrm{kg}$. This implies about $85 \%$ more $\mathrm{PM}_{2.5}$ emissions from the region than using the Andreae and Merlet (2001) recommendation of $9.1 \mathrm{~g} / \mathrm{kg}$. The physical basis for this increase is the inclusion of a larger contribution from smoldering combustion. The impact of this increase may be partially offset by any tendency for some of the initially unlofted particles to have a shorter atmospheric lifetime. Also, our evidence for this increase is far from conclusive, but not without merit. Thus, more measurements would be valuable. Finally, though pasture fires and deforestation fires are thought to consume roughly equal amounts of biomass in the Brazilian Amazon (Kauffman et al., 1998), pasture fires likely produce more of the particle and trace gas pollutants. However, the average fuel consumption on

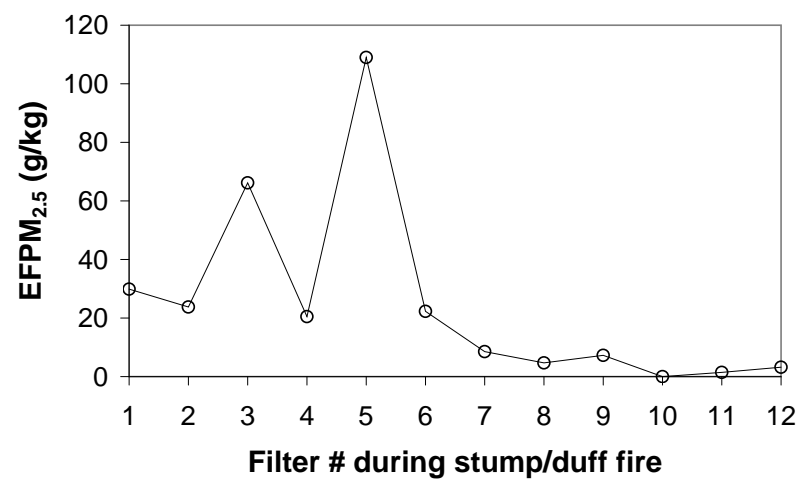

Fig. 6. A series of gravimetric determinations of $\mathrm{EFPM}_{2.5}$ acquired over the course of a laboratory fire described by Bertschi et al. (2003a). The first 6 samples were taken while a woody stump accounted for all the fuel consumption. Filters 7-9 sampled a mix of burning roots and duff. Samples 10-12 were of burning duff. The mass-loss weighted average EF for the woody stump is about $30 \mathrm{~g} / \mathrm{kg}$. This indicates that a similar EFPM 2.5 could be appropriate for the smoldering logs, which account for nearly all the unlofted emissions from residual smoldering combustion in Brazil.

primary deforestation fires could be increasing due to an increase in land conversion to mechanized agriculture (Christian et al., 2007).

There are three compounds that were measured only in the lab fires: glycolaldehyde, propanenitrile, and methylvinylether. Methylvinylether was detected by FTIR in only one lab fire and thus, we point out that it is emitted in trace amounts, but can't give a numerical recommendation. For the two other compounds, we estimate the emissions from field fires using the lab-measured ratio of the compound to the most similar species that was measured in the field. Specifically the lab ratio of propanenitrile to acrylonitrile (2.1) times the field acrylonitrile gives the estimate for propanenitrile for the field fires. (Acrylonitrile is also known as propenenitrile.) Similarly, the lab ratio glycolaldehyde/acetic acid (0.31) times the field acetic acid gives our estimates for field glycolaldehyde.

The final category of compounds to address is those that were measured only in the airborne canister sample of one above-average MCE fire (Yokelson et al., 2007a). We don't have information on the MCE dependence of these compounds nor can we make an estimate of variability. We simply report our one measurement in Table 4. 
3.3 Characteristics of biogenic and pyrogenic sources: Amazon to global

In the TROFFEE experiment our focus was improved measurements of the pyrogenic and biogenic emissions from the Amazon basin. In this section we show how the new information improves our understanding of tropical tropospheric chemistry at various scales.

3.3.1 Impact of major trace gas and particle sources in the Amazon basin

We start at the local scale noting that Karl et al. (2007a) measured average isoprene emissions from pristine tropical forest of $\sim 400 \pm 130 \mathrm{~g} / \mathrm{ha}$ day. This can be compared to the affect of burning a hectare of tropical forest (which typically requires less than one day) assuming a fuel consumption of $\sim 120 \pm 40 \mathrm{Mg} / \mathrm{ha}$ (Christian et al., 2007) and our primary deforestation $\mathrm{EF}$ for isoprene from Table $4(0.42 \pm 0.13 \mathrm{~g} / \mathrm{kg})$. The burned hectare releases a pulse of $\sim 50000 \pm 23000 \mathrm{~g}$ of isoprene, which is $>120$ days of production by an unburned hectare. However, only a small percentage of the Amazon basin burns every year $(\sim 2.5 \%)$ so we expect the emissions from plants to dominate the annual basin-wide isoprene budget. Explicitly, assuming four million $\mathrm{km}^{2}$ of tropical forest in the Amazon basin (Yokelson et al., 2007a) implies an annual biogenic isoprene source of $\sim 58 \pm 19 \mathrm{Tg}$. (The uncertainty quoted in the biogenic source does not include the uncertainty in forest area in this and the following estimates.) Approximately $2.0 \pm 0.5$ million ha of the Amazon are subjected to primary deforestation fires annually (http://www.obt.inpe.br/prodes/), which suggests that these fires consume about $2.4 \pm 1.0 \times 10^{11} \mathrm{~kg} / \mathrm{yr}$ of fuel. Kauffman et al. (1998) calculated that pasture fires in the Amazon basin consume roughly the same amount of biomass as primary deforestation fires. We combine the fuel consumption for these fire types with the EF for isoprene for these fire types from Table 4 and obtain an annual pyrogenic isoprene source of $0.28 \pm 0.16 \mathrm{Tg}(\sim 0.5 \%$ of biogenic source).

Analogous basin-wide annual estimates can be made for other individual NMOC emitted by both sources. For instance, the methanol to isoprene emission ratio for tropical forests was measured at $14 \%$ in Costa Rica (Karl et al., 2004) and 4\% during TROFFEE (Karl et al., 2007a). Taking an average value of $9 \pm 5 \%$ then implies an annual methanol source of $\sim 5.3 \pm 3.4 \mathrm{Tg}$ from intact Amazonian forest. Using the fuel consumption estimates above and the EF for methanol from Table 4 yields an annual Amazon-basin pyrogenic source of methanol of $\sim 2.1 \pm 1.1 \mathrm{Tg}$. In this case the fire source is about $40 \%$ of the plant source on an annual basis and the two sources would be comparable during the dry season.

Significant biogenic emissions of acetaldehyde, acetone, and monoterpenes have also been quantified from tropical forest. Taken together, Karl et al. (2004) and Karl et al. (2007a) imply that the sum of quantified non-isoprene emissions from tropical forest equals about $35 \pm 9 \%$ of isoprene. Increasing our estimate of isoprene emissions $(58 \mathrm{Tg})$ by $35 \%$ implies emissions of $79 \pm 33 \mathrm{Tg} / \mathrm{yr}$ of "known" NMOC from the Amazon basin. Using the sum of measured pyrogenic NMOC from Table 4 ( $\sim 26$ or $\sim 48 \mathrm{~g} / \mathrm{kg}$ for deforestation or pasture fires, respectively) yields a pyrogenic source of known NMOC from the Amazon basin of $\sim 18 \pm 11 \mathrm{Tg} / \mathrm{yr}$. The pyrogenic NMOC are about one-quarter of the biogenic NMOC in this case. Next, we note that the total mass of NMOC emitted by fires is actually about twice the measured mass of NMOC (see Sect. 2.4.) and the ratio of total/known, non-isoprene NMOC for plants could be similar (Goldstein and Galbally, 2007). If we double both the pyrogenic NMOC and the non-isoprene biogenic NMOC, we estimate the annual Amazonian pyrogenic and biogenic total NMOC at about $35 \pm 20$ and $99 \pm 53 \mathrm{Tg}$, respectively.

Biomass burning emissions are extremely reactive and the post-emission transformations depend partially on the speciation of the initial emissions, which is now better known as a result of TROFFEE. An important secondary process is $\mathrm{O}_{3}$ formation and Trentmann et al. (2005) showed that the details of the initial NMOC mix strongly influenced the modeled rate of $\mathrm{O}_{3}$ formation for a savanna fire plume. Therefore, use of the new TROFFEE EFNMOC could improve the modeled $\mathrm{O}_{3}$ formation for deforestation fire emissions.

Another important post-emission process is secondary aerosol formation. The post-emission mass growth factor for pyrogenic fine mode aerosol is probably highly variable and currently very uncertain with estimates ranging from 0 400\% (Reid et al., 1998, 2005; P. F. DeCarlo, personal communication). Here, for illustrative purposes, we assume that the $8 \pm 5 \mathrm{Tg}$ of $\mathrm{PM}_{2.5}$ initially emitted by Amazonian fires annually (Table 4) increases in mass by a factor of 1.8 during the first 1-3 days after emission due to secondary processes involving mostly co-emitted pyrogenic trace gases. If we also assume that the co-emitted inorganic, pyrogenic species such as $\mathrm{NO}_{x}, \mathrm{NH}_{3}$, and $\mathrm{SO}_{2}$ (Table 4) were $100 \%$ converted to aerosol nitrate, ammonium, and sulfate; then about $2.4 \mathrm{Tg}$ of the total regional mass growth in $\mathrm{PM}_{2.5}(\sim 6.4 \mathrm{Tg})$ would be due to these species. Thus, the inorganic species would account for $\sim 38 \%$ of the mass growth and about $62 \%$ ( $4 \mathrm{Tg}$ ) would be due to co-emitted pyrogenic NMOC. This implies that less than $\sim 11 \%$ of the co-emitted pyrogenic NMOC (35 Tg) would have oxidized and/or condensed on the fine particles (during 1-3 days) since we are ignoring changes in NMOC mass during oxidation. It's also likely that some of the secondary organic aerosol (SOA) would have come from the biogenic NMOC, which are more abundant regionally although less concentrated in initial plumes. A biogenic component to the Amazonian, moderately-aged, dry-season, fine-mode aerosol was not observed (or ruled out) by Echalar et al. (1998) even though they clearly measured a large biogenic contribution to the coarse-mode, dry-season aerosol (diameter $>2$ microns). They also observed large biogenic 
components to both modes in the wet season. In any case, our total assumed regional $\mathrm{PM}_{2.5}$ mass growth $(6.4 \mathrm{Tg})$ is equivalent to only $\sim 7.5 \%$ of our estimated total mass of NMOC emitted during the Amazonian dry-season by pyrogenic and biogenic sources together (assuming dry season equals onehalf annual for biogenics). The estimated organic part of the regional mass growth $(4 \mathrm{Tg})$ is less than $5 \%$ of the total regional NMOC. Thus, over the time scale of several days, $5 \%$ represents a rough upper limit on the percentage conversion via SOA for regional NMOC. This upper limit is consistent with the lower end of estimates of the fraction of biogenic emissions converted to PM by secondary processes, which range from $\sim 3$ to $\sim 66 \%$ (Andreae and Crutzen, 1997; Goldstein and Galbally, 2007). Clearly the percent conversion for individual NMOC varies greatly and more measurements are needed to support a rigorous overall accounting.

In light of the above budgets, it seems unlikely that $66 \%$ of the Amazonian biogenic NMOC condense on the Amazonian pyrogenic fine particles within 1-3 days of aging as might be inferred from Goldstein and Galbally (2007). A percentage conversion that high would represent a mass growth factor of > 8.2. No Amazonian field measurements support a growth factor this large at this time to our knowledge. Conversely, if $66 \%$ of biogenic NMOC did convert to secondary organic aerosol, then tropical forest regions would be producing well over ten times more fine particle mass than is currently included in conventional inventories of primary aerosol.

Further, the amount of regional SOA formation is constrained somewhat by source apportionment studies of the total aerosol mass in the Amazon dry season. Artaxo et al. (1998) made airborne measurements of aerosol characteristics in approximately the same regional haze investigated by Reid et al. (1998) during SCAR B. They observed an average regional value for total aerosol of $107 \mathrm{ug} / \mathrm{m}^{3}$ of which $78 \%$ was in the fine mode. These authors also performed source apportionment for the total aerosol mass and obtained a ratio for the biogenic/pyrogenic components of $34.6 \%$. Guyon et al. (2004) measured the average ratio for the biogenic/pyrogenic component of total aerosol mass as $35.5 \%$ in a tower-based study conducted during the Amazonian dry season. We can couple this with a rough estimate of the total pyrogenic, regional, dry-season, aerosol mass by multiplying our annual, regional, primary, pyrogenic $\mathrm{PM}_{10}$ (10 Tg, Table 4$)$ by 1.8 to obtain $18 \mathrm{Tg}$. If the biogenic component is $35 \%$ of $18 \mathrm{Tg}$, that implies a regional, dry-season, biogenic total aerosol mass of $6.3 \mathrm{Tg}$. This last value is $\sim 12 \%$ of the regional, dry-season, biogenic NMOC production of $\sim 50 \mathrm{Tg}$. Thus, $12 \%$ would be a large overestimate of the percentage conversion by SOA as we are ignoring a large biogenic component to the primary total aerosol mass and mass changes during oxidation. In summary, only $\sim 5 \%$ of the regional NMOC seem to be converted to aerosol within the Amazonian boundary layer on the time scale of 1-3 days. However, a larger percentage could convert to SOA on longer time scales and/or outside of the Amazonian boundary layer.
This could involve NMOC with lifetimes greater than several days and/or NMOC with shorter lifetimes that experience rapid transport to the free troposphere (Heald et al., 2005; Andreae et al., 2001).

\subsubsection{New global estimates of biogenic and pyrogenic NMOC}

Next we roughly characterize the total NMOC emissions from fires and plants at the global scale. We start by deriving a best estimate of global isoprene emissions from vegetation of $600 \mathrm{Tg} / \mathrm{yr}$ (range 500-750 Tg/yr) using the MEGAN model (Guenther et al., 2006). Using the same assumptions as above for both non-isoprene and unknown NMOC suggests a global biogenic NMOC source of $\sim 1000 \mathrm{Tg} / \mathrm{yr}$ (range $770-1400 \mathrm{Tg} / \mathrm{yr}$ ).

Our global, pyrogenic, NMOC estimate is derived in some detail. Coupling the sum of the EF for all our measured NMOC for deforestation fires (Table 4) with an estimate of biomass consumption in global deforestation fires (1330 Tg/yr, Andreae and Merlet, 2001 (uncertainty not provided, but large)) implies that global deforestation fires produce over $34 \mathrm{Tg} / \mathrm{yr}$ of identified NMOC. We are not considering the higher emissions from pasture maintenance fires in our global estimate. Our estimate does include the $12 \%$ increase we applied to our airborne EF for primary deforestation fires to account for residual smoldering combustion. Since we only measured about one-half the NMOC on a mass basis (Sect. 2.4), then the total annual NMOC from global deforestation fires should be about $69 \mathrm{Tg} / \mathrm{yr}$. This estimate and an analogous estimate for each main type of biomass burning listed by Andreae and Merlet (2001) are shown in Table 5. In Table 5, we have shown the biomass consumption by each type of burning, the total NMOC currently quantified for that type of burning, and we assume that real total NMOC are twice the measured total NMOC. This last assumption is conservative since the instrumentation required to measure half the NMOC was only available for tropical forest fires (in this work). In fact, for the category of biomass burning that produces the most global NMOC (cooking fires) only FTIR was available. The real conversion from measured to total NMOC for cooking fires could be closer to three. Also, as part of TROFFEE, Christian et al. (2007) reported a sum of NMOC measured by FTIR from burning dung (an important cooking fuel in China and India) that was $32 \%$ higher than the value we use (for wood cooking fires) in Table 5. The last column of Table 5 shows our estimate of total annual NMOC by type of fire and a conservative global sum of $466 \mathrm{Tg} / \mathrm{yr}$. For reasons given just above, the real global sum is probably over $500 \mathrm{Tg} / \mathrm{yr}$. Its worth noting that this global pyrogenic NMOC estimate is much larger than the $\sim 100 \mathrm{Tg} / \mathrm{yr}$ estimated earlier by Andreae and Merlet (2001). There are sound reasons for this increase. Mainly: 
Table 5. Estimate of the total NMOC production by global biomass burning.

\begin{tabular}{|c|c|c|c|c|c|}
\hline Type of fire & $\begin{array}{c}\text { fuel consumption }^{\mathrm{a}} \\
\mathrm{Tg} / \mathrm{yr}\end{array}$ & $\begin{array}{c}\text { NMOC } \\
\text { known } \\
\text { g/kg dry fuel }\end{array}$ & $\begin{array}{l}\text { measurement } \\
\text { method }\end{array}$ & $\begin{array}{c}\text { NMOC } \\
\text { est. total }^{\mathrm{f}} \\
\text { g/kg dry fuel }\end{array}$ & $\begin{array}{c}\text { NMOC } \\
\text { global } \\
\text { productiong } \\
\text { Tg/yr }\end{array}$ \\
\hline Savanna & 3160 & 12 & $\mathrm{FT}, \mathrm{PT}^{\mathrm{b}}$ & 24 & 76 \\
\hline Tropical deforestation & 1330 & 26 & FT, PT, PT-GC & 52 & 69 \\
\hline Cooking & 2701 & 27 & $\mathrm{FT}^{\mathrm{d}}$ & 54 & 146 \\
\hline Charcoal (production + use) & 196 & 120 & $\mathrm{FT}^{\mathrm{d}}$ & 240 & 47 \\
\hline Agricultural residue & 540 & 88 & $\mathrm{FT}, \mathrm{PT}^{\mathrm{b}}$ & 176 & 95 \\
\hline Extratropical Forest & 640 & 26 & see note $\mathrm{e}^{\mathrm{e}}$ & 52 & 33 \\
\hline Sum & 8567 & & & & 466 \\
\hline
\end{tabular}

${ }^{a}$ From Yevich and Logan as quoted in Andreae and Merlet (2001).

${ }^{b}$ Christian et al. (2003). FT indicates FTIR, PT indicates PTR-MS.

c This work. PT-GC indicates GC-PTR-MS.

${ }^{d}$ Bertschi et al. (2003b).

1. subsequent development of methods (FTIR, PTR-MS, and GC-PTR-MS) to quantify the previously poorlycharacterized emissions of reactive OVOC, that account for $\sim 80 \%$ of the NMOC in biomass burning smoke,

2. deployment of the new instrumentation on previously undersampled burning types such as cooking fires, charcoal kilns, agricultural waste, etc., and

3. the capability of PTR-MS to estimate the unknown NMOC.

In light of our updated estimate, biomass burning is easily the second largest source of global NMOC behind plants $(\sim 1000 \mathrm{Tg} / \mathrm{yr}$, see above) and well ahead of anthropogenic sources (142 Tg “C as NMOC”/yr, Middleton, 1995). Biomass burning has already long been recognized as the largest global source of primary fine carbonaceous particles (50-190 Tg/yr, diameter < 1 micron, Kreidenweis et al., 1999 (see their Table 4.1)). In addition, the $\sim 500 \mathrm{Tg} / \mathrm{yr}$ of NMOC from biomass burning should probably be added to the $\sim 1000 \mathrm{Tg} / \mathrm{yr}$ of NMOC from vegetation as major global sources of secondary organic aerosol.

Finally, it is a fair approximation to assume that biogenic NMOC emissions are given off in diffuse manner according to a predictable daily cycle that should be fairly straight forward to implement in local-global models. On the other hand, fire emissions are produced in concentrated pulses and undergo significant initial processing in an altered chemical regime whose best depiction in local-global models is still unknown (Trentmann et al., 2005). e Use values from this work for tropical forest.

${ }^{\mathrm{f}}$ Multiply measured value by two (see Sect 2.4 and 3.3).

g Identified NMOC sum to $233 \mathrm{Tg}, \mathrm{C}$ in total NMOC is $\sim 330 \mathrm{Tg}$.

\subsection{Sugar cane}

In many heavily populated areas of the tropics and subtropics large areas of sugar cane are burned, which can add to regional air quality concerns (Lara et al., 2005; Cançado et al., 2006). Top sugar producing areas (2004 data) in order are: southern Brazil, India, China, Thailand, Pakistan, Mexico, Colombia, Australia, Philippines, southern US (including Hawaii), Indonesia, and Cuba (http://www.fao.org/ statistics/yearbook/vol_1_1/pdf/b08.pdf). The most common sugar cane varieties take two years to mature. In this time, dried leaves and weeds accumulate and the most economical method of separating them from the cane is to burn the field just before harvest. This also eliminates pests that can hinder manual harvesting. About $20 \mathrm{Mg} /$ ha of biomass is consumed in these fires and Brazil alone has about 4500000 ha planted in sugar cane with over half of these hectares in densely populated São Paulo State (Lara et al., 2005). There are sugar cane varieties that don't require burning before harvest, but there are barriers to adopting these varieties: lower yield, less economical, and potential job loss (over a million workers are employed by the traditional sugar cane industry in Brazil alone (Lara et al., 2005)).

Only a few studies exist on the initial particle and trace gas emissions from burning sugar cane and their influence on the atmosphere. These studies were in São Paulo State, Brazil, where over $50 \%$ of the world's sugar cane is produced (Yevich and Logan, 2003). At a sampling site about $4 \mathrm{~km}$ from downtown Piracicaba (population 320 000) and $1 \mathrm{~km}$ from a sugar cane plantation, sugar cane burning contributed $60 \%$ of annual $\mathrm{PM}_{2.5}$. In the same city, particle emissions from sugar cane fires were associated with increased hospital visits for respiratory problems by children and elderly patients (Cançado et al., 2006). Table 3 gives our EFPM 2.5 for 
sugar cane burning as $2.17 \mathrm{~g} / \mathrm{kg}$. However, this value, while accurate, is from a single laboratory fire that burned at an MCE that is higher than normally obtained in the field for biomass burning. We have no field measurements to indicate the MCE of a typical sugar cane fire, but it is likely lower and that would imply a larger $\mathrm{EFPM}_{2.5}$ (e.g. see Fig. 5). Since emission ratios to $\mathrm{CO}$ normally vary less strongly with MCE than do EF, it is of value to also express our $\mathrm{PM}_{2.5}$ data in this way. On a mass basis $\mathrm{PM}_{2.5} / \mathrm{CO}$ is 0.077 , which is equivalent to $88 \mu \mathrm{g} / \mathrm{m}^{3}$ per ppm of CO. These ratios are well within the "normal range" for biomass burning.

To our knowledge, the only previously published measurements of gas-phase emissions from sugar cane burning are by da Rocha et al. (2003). They used $\mathrm{NaOH}$-impregnated cellulose filters to measure gaseous acidic species (formic acid, acetic acid, $\mathrm{HCl}, \mathrm{HNO}_{3}$, and $\mathrm{SO}_{2}$ ) only 1-2 $\mathrm{m}$ from a sugar cane fire near the city of Araraquara. These authors report a molar emission ratio of formic to acetic acid of 2.95. In contrast, we find that acetic acid is the dominant organic acid $($ acetic/formic $=5.72$, or formic/acetic $=0.175$ ). Thus our acetic/formic ratio is 17 times higher, but neither study is extensive enough to fully assess natural variation in this ratio. Whereas Lara et al. (2005) found that ambient $\mathrm{PM}_{2.5}$ increased during the cane burning season, da Rocha et al. obtained results for ambient gases that are harder to rationalize. Their ambient formic and acetic levels decreased during the burning season even though they are major biomass burning products. On the other hand, minor burning products such as $\mathrm{HCl}, \mathrm{SO}_{2}$, and $\mathrm{HNO}_{3}$ increased by $100-300 \%$ during the burning season.

Bagasse is the residual, fibrous biomass left behind after milling (compressing) the cane. It can be used for animal feed and in the manufacture of paper, but it is also burned to produce electricity and represents a second, as yet uncharacterized, emissions source for sugar cane. Also, though sugar cane and bagasse burning together account for only a small fraction of the total annual biomass burned on a global scale, sugar cane fields are typically located closer to urban or semiurban areas and thus burning sugar cane may have a larger relative health impact.

\section{Conclusions}

Detailed measurements were made of the emissions from laboratory fires burning tropical forest fuels as part of the Tropical Forest and Fire Emissions Experiment (TROFFEE). In most cases, about one-third of the fuel chlorine ended up in the particles and about one-half in the ash. About 50\% of the total mass of volatile NMOC emitted by these fires could be identified. The lab fire emission factors $(\mathrm{EF})$ were integrated with EF obtained during the TROFFEE airborne and ground-based field campaigns, and with field measurements of fuel consumption. This procedure produced recommended EF for all measured species for both primary de- forestation fires and pasture maintenance fires. Most of the NMOC and particle EF are $20-80 \%$ larger than previously suggested; mostly because our new method includes a significant contribution from the recently-measured, initiallyunlofted emissions from smoldering logs. The TROFFEE $\mathrm{EFPM}_{2.5}$ is $14.8 \mathrm{~g} / \mathrm{kg}$ for primary deforestation fires and $18.7 \mathrm{~g} / \mathrm{kg}$ for pasture maintenance fires. These EF imply a pyrogenic $\mathrm{PM}_{2.5}$ source for the Amazon that is $84 \%$ larger than a widely-used previous recommendation for tropical deforestation $\mathrm{EFPM}_{2.5}(9.1 \mathrm{~g} / \mathrm{kg})$.

Plants are the main source of isoprene in the Amazon basin, but much larger isoprene concentrations can be generated in smoke plumes. Even though plants are the main global source of methanol, fire can be a comparable source of methanol in the Amazon basin during the dry season. Fires are the main regional source of $\mathrm{CO}$, but more total NMOC are emitted by plants and they dominate the $\mathrm{OH}$ reactivity of the region (Karl et al., 2007a). Coupling source apportionment studies and an estimate of secondary aerosol formation in the Amazon with our regional trace gas and $\mathrm{PM}_{2.5}$ budgets for the dry season suggests that about 5\% of the total mass of pyrogenic and biogenic NMOC could contribute to secondary aerosol formation within the regional boundary layer on a time scale of 1-3 days. A conservative estimate of global pyrogenic NMOC is $\sim 466 \mathrm{Tg} / \mathrm{yr}(250-$ $630 \mathrm{Tg} / \mathrm{yr}$ ), which clearly establishes biomass burning as the second largest global source of NMOC (after plants) and a potential major global source of secondary aerosol. A few emission ratios (ER) appropriate for sugar cane burning were also measured, which may help estimate the air quality impacts of burning this major crop.

Acknowledgements. This research was supported primarily by NSF grant ATM0228003. Yokelson was also supported by the Interagency Joint Fire Science Program, the Rocky Mountain Research Station, Forest Service, U.S. Department of Agriculture (agreements INT-97082-RJVA, RMRS 99508 RJVA, and 03-UV1222049-046). The National Center for Atmospheric Research is sponsored by the National Science Foundation. This research benefited from the authors collaboration with the Large Scale Biosphere-Atmosphere Experiment in Amazônia (LBA). The tropical plants used in this study, with the exception of the dambo grass, were grown for the Ecology and Evolutionary Biology teaching collection in the simulated tropical lowlands room (114) at the University of Colorado Biology Department green house and kindly donated by T. Lemieux and C. C. Grayless.

Edited by: J. Kaiser 


\section{References}

Andreae, M. O. and Merlet, P.: Emission of trace gases and aerosols from biomass burning, Global Biogeochem. Cy., 15(4), 955-966, 2001.

Andreae, M. O., Artaxo, P., Fischer, H., et al.: Transport of biomass burning smoke to the upper troposphere by deep convection in the equatorial region, Geophys. Res. Lett., 28, 951-954, 2001.

Andreae, M. O. and Crutzen, P. J.: Atmospheric aerosols: biogeochemical sources and role in atmospheric chemistry, Science, 276, 1052-1056, 1997.

Artaxo, P., Fernandes, E. T., Martins, J. V., Yamasoe, M. A., Hobbs, P. V., Maenhaut, W., Longo, K. M., and Castanho, A.: Largescale aerosol source apportionment in Amazonia, J. Geophys. Res., 103, 31 837-31 847, 1998.

Bertschi, I. T., Yokelson, R. J., Ward, D. E., Babbitt, R. E., Susott, R. A., Goode, J. G., and Hao, W. M.: Trace gas and particle emissions from fires in large-diameter and belowground biomass fuels, J. Geophys. Res., 108, 8472, doi:10.1029/2002JD002100, 2003a.

Bertschi, I. T., Yokelson, R. J., Ward, D. E., Christian, T. J., and Hao, W. M.: Trace gas emissions from the production and use of domestic biofuels in Zambia measured by open-path Fourier Transform Infrared Spectroscopy, J. Geophys. Res., 108, 8469, doi:1029/2002/D002158, 2003b.

Cançado, J. E. D., Saldiva, P. H. N., Pereira, L. A. A., et al.: The impact of sugar-cane burning emissions on the respiratory system of children and the elderly, Environ. Health Persp., 114, 725729, 2006.

Christian, T. J., Kleiss, B., Yokelson, R. J., Holzinger, R., Crutzen, P. J., Hao, W. M., Saharjo, B. H., and Ward, D. E.: Comprehensive laboratory measurements of biomass-burning emissions: 1 . Emissions from Indonesian, African, and other fuels, J. Geophys. Res., 108(D23), 4719, doi:10.1029/2003JD003704, 2003.

Christian, T. J., Kleiss, B., Yokelson, R. J., Holzinger, R., Crutzen, P. J., Hao, W. M., Shirai, T., and Blake, D. R.: Comprehensive laboratory measurements of biomass-burning emissions: 2. First intercomparison of open-path FTIR, PTRMS, and GC-MS/FID/ECD, J. Geophys. Res., 109, D02311, doi:10.1029/2003JD003874, 2004.

Christian, T. J., Yokelson, R. J., Carvalho Jr., J. A., Griffith, D. W. T., Alvarado, E. C., Santos, J. C., Neto, T. G. S., Veras, C. A. G., and Hao, W. M.: The tropical forest and fire emissions experiment: trace gases emitted by smoldering logs and dung on deforestation and pasture fires in Brazil, J. Geophys. Res., 112, D18308, doi:10.1029/2006JD008147, 2007.

Crutzen, P. J., Delany, A. C., Greenberg, J., Haagenson, P., Heidt, L., Lueb, R., Pollock, W., Seiler, W., Wartburg, A., and Zimmerman, P.: Tropospheric chemical composition measurements in Brazil during the dry season, J. Geophys. Res., 2, 233-256, 1985.

da Rocha, G. O., Franco, A., Allen, A. G., and Cardoso, A. A.: Sources of atmospheric acidity in an agricultural-industrial region of Sao Paulo State, Brazil, J. Geophys. Res., 108(D7), 4207, doi:10.1029/2002JD002567, 2003.

Echalar, F., Artaxo, P., Martins, J. V., Yamasoe, M., Gerab, F., Maenhaut, W., and Holben, B.: Long-term monitoring of atmospheric aerosols in the Amazon Basin: Source identification and apportionment, J. Geophys. Res., 103, 31 849-31 864, 1998.

Ferek, R. J., Reid, J. S., Hobbs, P. V., Blake, D. R., and Liousse,
C.: Emission factors of hydrocarbons, halocarbons, trace gases, and particles from biomass burning in Brazil, J. Geophys. Res., 103(D24), 32 107-32 118, doi:10.1029/98JD00692, 1998.

Goldstein, A. H. and Galbally, I. E.: Known and unexplored organic constituents in the Earth's atmosphere, Environ. Sci. Technol., 41, 1514-1521, 2007.

Goode, J. G., Yokelson, R. J., Susott, R. A., and Ward, D. E.: Trace gas emissions from laboratory biomass fires measured by openpath FTIR: Fires in grass and surface fuels, J. Geophys. Res., 104(D17), 21 237-21 245, doi:10.1029/1999JD900360, 1999.

Greenberg, J., Lee, B., Helmig, D., and Zimmerman, P.: Fully automated gas chromatograph-flame ionization detector system for the in situ determination of atmospheric non-methane hydrocarbons at low parts per trillion concentration, J. Chromatogr., 676, 389-398, 1994.

Griffith, D. W. T.: Synthetic calibration and quantitative analysis of gas phase infrared spectra, Appl. Spectrosc., 50, 59-70, 1996.

Guenther, A., Karl, T., Harley, P., Wiedinmyer, C., Palmer, P. I., and Geron, C.: Estimates of global terrestrial isoprene emissions using MEGAN (Model of Emissions of Gases and Aerosols from Nature), Atmos. Chem. Phys., 6, 3181-3210, 2006,

http://www.atmos-chem-phys.net/6/3181/2006/.

Guyon, P., Graham, B., Roberts, G. C., Mayol-Bracero, O. L., Maenhaut, W., Artaxo, P., and Andreae, M. O.: Sources of optically active aerosol particles over the Amazon forest, Atmos. Environ., 38, 1039-1051, 2004.

Heald, C. L., Jacob, D. J., Park, R. J., Russell, L. M., Huebert, B. J., Seinfeld, J. H., Liao, H., and Weber, R. J.: A large organic aerosol source in the free troposphere missing from current models, Geophys. Res. Lett., 32, L18809, doi:10.1029/2005GLO23831, 2005.

Hoffa, E. F., Wakimoto, R. H., Ward, D. E., Hao, W. M., and Susott, R. A.: Seasonality of carbon emissions from biomass burning in a Zambian savanna, J. Geophys. Res., 104, 13 841-13 853, 1999.

Karl, T. G., Guenther, A., Yokelson, R. J., Greenberg, J., Potosnak, M. J., Blake, D. R., and Artaxo P.: The tropical forest and fire emissions experiment: Emission, chemistry, and transport of biogenic volatile organic compounds in the lower atmosphere over Amazonia, J. Geophys. Res., 112, D18302, doi:10.1029/2007JD008539, 2007a.

Karl, T. G., Christian, T. J., Yokelson, R. J., Artaxo, P., Hao, W. M., and Guenther, A.: The tropical forest and fire emissions experiment: Method evaluation of volatile organic compound emissions measured by PTR-MS, FTIR, and GC from tropical biomass burning, Atmos. Chem. Phys., 7, 5883-5897, 2007b, http://www.atmos-chem-phys.net/7/5883/2007/.

Karl, T., Potosnak, M., Guenther, A., Clark, D., Walker, J., Herrick, J. D., and Geron, C.: Exchange processes of volatile organic compounds above a tropical rain forest: Implications for modeling tropospheric chemistry above dense vegetation, J. Geophys. Res., 109, D18306, doi:10.1029/2004JD004738, 2004.

Kauffman, J. B., Cummings, D. L., and Ward, D. E.: Fire in the Brazilian Amazon 2: biomass, nutrient pools and losses in cattle pastures, Oecologia, 113, 415-427, doi:10.1007/s004420050394, 1998.

Keene, W. C., Lobert, J. M., Crutzen, P. J., Maben, J. R., Scharffe, D. H., Landmann, T., Hély, C., and Brain, C.: Emissions of major gaseous and particulate species during experimental burns of southern African biomass, J. Geophys. Res., 111, D04301, 
doi:10.1029/2005JD006319, 2006.

Korontzi, S., Ward, D. E., Susott, R. A., Yokelson, R. J., Justice, C. O., Hobbs, P. V., Smithwick, E. A. H., and Hao, W. M.: Seasonal variation and ecosystem dependence of emission factors for selected trace gases and PM for southern African savanna fires, J. Geophys. Res., 108(D24), 4758, doi:10.1029/2003JD003730, 2003.

Kreidenweis, S., Tyndall, G., Barth, M., Dentener, F., Lelieveld, J., and Mozurkewich, M.: Aerosols and clouds, in: Atmospheric Chemistry and Global Change, edited by: Brasseur, G. P., Orlando, J. J., and Tyndall, G. S., Oxford University Press, New York, USA, 117-155, 1999.

Lara, L. L., Artaxo, P., Martinelli, L. A., Camargo, P. B., Victoria, R. L., and Ferraz, E. S. B.: Properties of aerosols from sugarcane burning emissions in Southeastern Brazil, Atmos. Environ., 39, 4627-4637, 2005.

Lindinger, W., Jordan, A., and Hansel, A.: Proton-transfer-reaction mass spectrometry (PTR-MS): on-line monitoring of volatile organic compounds at pptv levels, Chem. Soc. Rev., 27, 347-375, doi:10.1039/a827347z, 1998.

Middleton, P: Sources of air pollutants, in: Composition, chemistry, and climate of the atmosphere, edited by: Singh, H., Van Nostrand Reinhold, New York, USA, 88-119, 1995.

Rasmussen, R. A. and Khalil, M. A. K.: Isoprene over the Amazon Basin, J. Geophys. Res., 93(D2), 1417-1421, 1988.

Reid, J. S., Hobbs, P. V., Ferek, R. J., Blake, D. R., Martins, J. V., Dunlap, M. R., and Liousse, C.: Physical, chemical, and optical properties of regional haze dominated by smoke in Brazil, J. Geophys. Res., 103, 32 059-32 080, 1998.

Reid, J. S., Koppmann, R., Eck, T. F., and Eleuterio, D. P.: A review of biomass burning emissions part II: intensive physical properties of biomass burning particles, Atmos. Chem. Phys., 5, 799825,2005 , http://www.atmos-chem-phys.net/5/799/2005/.

Trent, A., Davies, M. A., Fisher, R., Thistle, H., and Babbitt, R.: Evaluation of optical instruments for real-time, continuous monitoring of smoke particulates, Tech. Rep. 0025-2860-MTDE, Missoula Technology and Development Center, USDA Forest Service, Missoula, MT, USA, 38 pp., 2000.
Trentmann, J., Yokelson, R. J., Hobbs, P. V., Winterrath, T., Christian, T. J., Andreae, M. O., and Mason, S. A.: An analysis of the chemical processes in the smoke plume from a savanna fire, J. Geophys. Res., 110, D12301, doi:10.1029/2004JD005628, 2005.

Ward, D. E. and Radke, L. F.: Emissions measurements from vegetation fires: a comparative evaluation of methods and results, in: Fire in the environment: the ecological, atmospheric and climatic importance of vegetation fires, edited by: Crutzen, P. J. and Goldammer, J. G., John Wiley, New York, 53-76, 1993.

Ward, D. E. and Hardy, C. C.: Smoke emissions from wildland fires, Environ. Int., 17, 117-134, 1991.

Yokelson, R. J., Karl, T., Artaxo, P., Blake, D. R., Christian, T. J., Griffith, D. W. T., Guenther, A., and Hao, W. M.: The tropical forest and fire emissions experiment: overview and airborne fire emission factor measurements, Atmos. Chem. Phys., 7, 51755196, 2007a, http://www.atmos-chem-phys.net/7/5175/2007/.

Yokelson, R. J., Urbanski, S., Atlas, E., et al.: Emissions from forest fires near Mexico City, Atmos. Chem. Phys., 7, 5569-5584, 2007b, http://www.atmos-chem-phys.net/7/5569/2007/.

Yokelson, R. J., Bertschi, I. T., Christian, T. J., Hobbs, P. V., Ward, D. E., and Hao, W. M.: Trace gas measurements in nascent, aged, and cloud processed smoke from African savanna fires by airborne Fourier transform infrared spectroscopy (AFTIR), J. Geophys. Res., 108, 8478, doi:10.1029/2002JD002322, 2003.

Yokelson, R. J. and Bertschi, I. T.: Vibrational spectroscopy in the study of fires, in: Handbook of Vibrational Spectroscopy, edited by: J. M. Chalmers and P. R. Griffiths, John Wiley and Sons Ltd., Chichester, UK, 2879-2886, 2002.

Yokelson, R. J., Ward, D. E., Susott, R. A., Reardon, J., and Griffith, D. W. T.: Emissions from smoldering combustion of biomass measured by open-path Fourier Transform Infrared Spectroscopy, J. Geophys. Res., 102(D15), 18 865-18 877, 1997.

Yokelson, R. J., Griffith, D. W. T., and Ward, D. E.: Openpath Fourier Transform Infrared studies of large-scale laboratory biomass fires, J. Geophys. Res., 101, 21 067-21 080, 1996. 